\title{
Determination of Monitoring Parameters for Fatigue Behavior of Steel-Concrete Composite Bridge Girders with Welded Full Depth Transverse Stiffeners
}

\author{
Baris Gunes $^{1, *}$, Alper Ilki ${ }^{2}$ (D) and Namik Kemal Oztorun ${ }^{1}$ \\ 1 Civil Engineering Department, Engineering Faculty, Istanbul University-Cerrahpasa, Avcilar, \\ Istanbul 34320, Turkey; kemal@istanbul.edu.tr \\ 2 Civil Engineering Faculty, Istanbul Technical University, Maslak, Istanbul 34469, Turkey; ailki@itu.edu.tr \\ * Correspondence: bgunes@istanbul.edu.tr; Tel.: +90-532-748-88-10
}

Received: 13 December 2019; Accepted: 27 December 2019; Published: 30 December 2019

\begin{abstract}
In this study, parameters that should be monitored during the service life of a bridge and the relationship between the parameters and damage are investigated in order to predict the fatigue damages in steel-concrete composite bridge girders with welded full depth transverse stiffeners. In this context, static and fatigue tests are carried out on steel-concrete composite beam specimens with welded full depth transverse stiffeners. Load-deflection behavior of specimens is determined by these monotonic tests. In the fatigue tests, the specimens are subjected to cyclic loading with various stress ranges, and stress range - number of cycles (S-N) data is obtained. Fatigue crack and fatigue fracture are observed in the first two specimens with the highest stress range applied. As expected, the fatigue crack occurred at the point where the stiffener is welded to the bottom flange. During the tests, dynamic deflection and strain measurements are performed at the critical points throughout the cyclic loading. The parameters which are more critical in terms of fatigue behavior and should be monitored are determined by examining the relationship between the obtained data from these measurements and fatigue damage. Discussions and evaluations are made on the level of safety presented in the relevant code by the comparison of the obtained results from fatigue tests with the code and the important studies in the literature. Finally, the specimens without fatigue fracture were tested under monotonic loading to determine the residual strength. Accordingly, the change in the load-deflection behavior after cyclic loading is demonstrated.
\end{abstract}

Keywords: monitoring; fatigue; steel-concrete composite bridge girder; welded full depth transverse stiffener

\section{Introduction}

Fatigue of metallic materials is an essential factor that affects the service life of many engineering structures. The first systematic studies on fatigue are made by August Wöhler in the 1850s and 1860s. Wöhler found the concept of stress range-number of cycles diagram (S-N) and showed that the fatigue behavior depends on the stress range rather than the highest stress [1]. In the 20th century, the fatigue mechanism of metallic materials began to be examined with the advances in the microscopic examination. The formation of a fatigue mechanism has been observed in materials exposed to cyclic loads. In this mechanism, initially, micro-cracks are formed which cannot be seen macroscopically. These cracks grow and cause the collapse of the element over time [2].

Welded steel bridges, which are highly prone to fatigue, have been built frequently since the 1950s [3]. In the 1960s, the first fatigue cracks began to be seen on the beams with stiffened flanges. In the 1970s and 1980s, fatigue cracks are frequently encountered on the other welded connections. 
In the study of Fisher et al. [4], it is stated that, in the United States, welded joints are used on 123,000 bridges, 50,000 are built between 1955 and 1975, and about 10\% of them have fatigue-sensitive details. Kazuhiro et al. [5] and Al-Emrani et al. [6] have identified the details related to the fatigue damages that commonly observed on bridges. Fatigue damages can occur in various forms of welded connections. The welded connections with high stress concentrations, eccentricity and permanent (residual) stresses are considerably prone to fatigue damages. Discontinuities caused by welds and the imperfections on the weld surface most likely cause stress concentrations which trigger crack formation [7].

A stress-based approach (S-N curve approach) is determined in the fatigue design of bridges in AASHTO LRFD [8], which is a comprehensive specification on bridges. In this approach, it is assumed that the structural elements do not have initial cracks, and the stresses and strains remain within the elastic limits. In AASHTO LRFD [8], the fatigue behavior of steel bridges is divided into 8 different categories as $\mathrm{A}, \mathrm{B}, \mathrm{B}^{\prime}, \mathrm{C}, \mathrm{C}^{\prime}, \mathrm{D}, \mathrm{E}$ and $\mathrm{E}^{\prime}$ according to their connection regions, details and types. Category $\mathrm{A}$ represents the highest fatigue strength while Category $\mathrm{E}^{\prime}$ represents the lowest fatigue strength. In Section 6.6.1.2.3 of AASHTO LRFD [8], the fatigue critical details and their categories are presented as "plain material away from any welding", "connected material in mechanically fastened joints", "welded joints components of built-up members", "welded stiffener connections", "transversely or longitudinally loaded welded attachments", "orthotropic deck details".

Welding of the transverse stiffeners to the flanges of the steel beam is a commonly used detail in practice. However, fatigue damages may occur in structural systems which are subjected to cyclic loads such as bridges with these details. The strength of this detail under cyclic loads is determined by fatigue tests in various studies [9-16]. This detail is included in Category $C^{\prime}$ in AASHTO LRFD [8]. The fatigue behavior of steel beams with transverse stiffeners is examined in NCHRP's report 147 [9]. In the study, some of the stiffeners are welded only to the web and some to both the web and flanges. Regardless of the geometry of the stiffener, in the specimens where the stiffeners are only welded to the web, all cracks are formed at or around the welding tip. In the specimens where the stiffeners are welded to the web and flanges, fatigue cracks started forming on the bottom flange and advanced through the web. Klippstein and Schilling [11] investigated the fatigue behavior of the tension specimens having transverse stiffeners where welding is done under ideal and controlled conditions. At the end of cyclic loading, the fatigue strength of the specimens is found in category B'. Wright [13] and Woo et al. [15] examined the fatigue behavior of steel beams with transverse stiffeners under variable amplitude loading. Jang et al. [16] compared the propagation of fatigue cracks in the tests with crack propagation models in the literature. In some studies, the propagation of the fatigue cracks is examined with finite element analysis [17,18]. Avoiding the welding of transverse stiffeners to the steel beam flange under tension will increase fatigue life. However, the stiffeners are generally welded to the steel beam flanges in practice for several purposes like preventing local buckling, forming connections for steel braces etc.

In report 102 of NCHRP [19], it is stated that the effect of the minimum stress and the structural steel class on fatigue behavior are very mild. Schilling et al. [20] examined the effect of the minimum stress, load spectrum and structural steel class on fatigue behavior under constant and variable amplitude loading. Fisher et al. [4] stated that the material properties of the steel types used in the structural field have a negligible effect on the fatigue behavior of the bridges. Stephens et al. [2] stated that the fatigue life of small-scale specimens might be longer than large scale ones. The possibility of fatigue crack formation increases with the increase of surface of the material.

Non-composite steel beams are generally used in the studies conducted to determine the fatigue categories. However, there are also fatigue studies where steel-concrete composite beams are used. Many studies have been conducted on the fatigue behavior of the connections between steel and concrete [21-28]. Albrecht \& Lenwari [29] and El-Zohairy et al. [30] examined the ultimate strength and fatigue behavior of steel-concrete composite beams repaired by post-tensioning. When the fatigue behavior of CFRP strengthened steel-concrete composite beams is examined, it is observed that CFRP increases the live load capacity [31]. Lin et al. [32] investigated the fatigue behavior of the negative moment region of continuous steel-concrete composite beams. Yen et al. [33] tested steel-concrete 
composite beams under static and dynamic loads. In the study, the effect of reinforcement configuration on the ultimate capacity and fatigue strength is investigated. In addition to bridges, there have been many studies on fatigue behavior and damage localization of steel buildings exposed to the seismic effects [34-36].

Modares \& Waksmanski, [37] provided an overview of the structural health monitoring (SHM) systems used on steel bridges. In the study, it is stated that the service life of the bridge will be reduced if the damages caused by unpredictable mechanical and environmental effects are not detected in time and repaired effectively. It is indicated that early warnings made by SHM systems can prevent high repair costs and catastrophic failures. It is also emphasized that the initial and maintenance costs of SHM systems are very low when compared with the renewal cost of a bridge and the loss of human life.

The I-35W bridge over the Mississippi River in Minneapolis, Minnesota, collapsed suddenly on 1 August 2007, resulting in the deaths of 13 people and injuries of 145 people [38]. This situation and other bridge failures have once again emphasized the importance of structural health monitoring systems.

In the SHM systems, the most common measurements are acceleration-based dynamic tests [39-46]. However, there are still some difficulties in the acceleration-based SHM tests. For instance, the identified structural modal frequencies (e.g., frequencies) are considered being insensitive to a specific local damage even near the accelerometer [47].

During the last decades, studies about fatigue performance evaluation that were based on field monitoring data were conducted [48]. Over the last decades, many structural health monitoring (SHM) systems were established to continuously monitor the in-service condition of long-span bridges [49-54]. Of the wide variety of monitoring data, dynamic strain data are of great significance for fatigue evaluation of welded details because they can be used to obtain stress ranges and the number of load cycles [55]. Connor et al. [56] conducted a fatigue reliability assessment of the I-39 northbound. Wisconsin River Bridge is based on 4-month SHM strain data. A case study focusing on the fatigue performance of the welded details of the girder of the Runyang Bridge was conducted according to 4-year monitoring strain data [57]. Frangopol et al. [58] proposed an approach for a structural reliability assessment by monitoring strain data and demonstrated the method by using recorded data of an in-service highway bridge.

The detail commonly used in practice and defined as "welded full depth transverse stiffener" in AASHTO LRFD [8] is used on the specimens in this study. Fatigue tests in the literature related to this detail are done with non-composite steel beams. Although composite beams are used in some experimental studies under cyclic loads, the "welded full depth transverse stiffener" connection detail is not examined in these studies. Strain based monitoring systems have recently been used in steel bridges. Strain-based measurements are carried out for fatigue on the critical regions of some important structures such as inclined suspension bridges and suspended bridges. These measurements are usually made on the cables of bridges and rib to deck/web plate connections. Monitoring on the "welded full depth transverse stiffener" detail was not performed. Furthermore, there is no monitoring data for the fatigue fracture of this detail. Therefore, the change in strains and their relationship with the damage formation are not known at the stages of the beginning of fatigue, crack formation and fatigue fracture.

In this study, it is aimed to predict fatigue damages on in-service steel-concrete composite bridges with welded full depth transverse stiffener connection detail. In these bridges, it is also aimed to determine which structural health monitoring technique should be used for the detection of fatigue, and the relationship between the obtained data and damages. It is believed by the authors that this study has a strong importance due to various aspects as; examining the fatigue behavior of the "welded full depth transverse stiffener connection" detail category using steel-concrete composite specimens; revealing the relationship between the changes in deflection/stiffness/strain and fatigue damages during cyclic loading; determining the type of structural health monitoring technique that should be used to predict fatigue damages in bridges with this detail. 
Five tests (one monotonic and four cyclic) are performed within this context. Initially, the load-deflection behavior of the specimens is determined by the monotonic test. Then, the fatigue behavior of the specimens is examined by subjecting the specimens to the cyclic loads at various stress ranges. The fatigue fracture occurred in two specimens with the highest stress range applied. In the cyclic loading tests, deflections and strains at the critical points of the specimens are measured during whole loading. The type of the structural health monitoring technique that should be used and the type of the data that should be monitored with these systems are determined by examining the relationship between the data obtained from these measurements and fatigue behavior. The results obtained from fatigue tests are compared with AASHTO LRFD [8], and general discussions are made about the level of structural safety presented in the code. In addition, after cyclic loading, the specimens without fatigue fractures are examined under monotonic loading to determine the change in the residual performance. The presented work is a part of a PhD. Thesis of Istanbul University [59].

\section{Materials and Methods}

\subsection{Material Properties}

In this section, properties of the concrete, steel and rebar materials used in this study are presented. Five standard cylinder concrete samples $(150 \times 300 \mathrm{~mm})$ are tested 28 days after casting to achieve the compressive strength of concrete in the scope of material tests considering the recommendations presented in TS EN 12390-3 [60]. Six coupon samples are taken from the web and flange of the steel sections, and tensile tests are performed on these samples according to the rules given in TS EN ISO 6892-1 [61]. Five rebar tensile tests are performed to obtain the material properties of rebar used in the specimens based on the rules presented in TS EN ISO 6892-1 [61]. The average values of the obtained properties for concrete, steel section and rebar materials are summarized in Table 1. The standard deviation of the concrete strength and modulus of elasticity of concrete are 2.56 and $440 \mathrm{MPa}$, respectively.

Table 1. Material properties of concrete, steel section and rebar.

\begin{tabular}{ccccc}
\hline Properties & Concrete & Flange of Steel Section & Web of Steel Section & Rebar \\
\hline Concrete strength, $\mathrm{f}_{\mathrm{c}}^{\prime}(\mathrm{MPa})$ & 24.19 & - & - & - \\
Yield strength, $\mathrm{f}_{\mathrm{y}}(\mathrm{MPa})$ & - & 378 & 360 & 588 \\
Ultimate strength, $\mathrm{f}_{\mathrm{u}}(\mathrm{MPa})$ & - & 521 & 519 & 634 \\
Modulus of elasticity, $\mathrm{E}(\mathrm{MPa})$ & 20,328 & 200,000 & 200,000 & 195,000 \\
\hline
\end{tabular}

\subsection{Specimen Design}

The scale of the produced specimens is approximately $1 / 6$ of a typical steel-concrete composite bridge beam (Figure 1). In the literature, there are studies in which similarly scaled specimens are used $[28,31,33]$. Each steel-concrete composite beam is formed with an IPE140 steel section and a $350 \mathrm{~mm}$ wide, $50 \mathrm{~mm}$ thick site-cast concrete deck (Figure 2). The length of the beams is $2800 \mathrm{~mm}$. There are two $150 \mathrm{~mm}$ long reinforced concrete blocks on support zones at both ends of the beams (Figure 3). Six mm thick stiffeners are used on both sides of the web of I-section at the regions on the concrete blocks at beam supports, and at the regions of load application points (Figure 3). These stiffeners are manually welded to the bottom flange, top flange and web of the steel beams with $3 \mathrm{~mm}$ weld size (thickness). This detail is typically applied on many highway bridges and determines the fatigue category of the bridge in general. This type of detail is categorized as type $C^{\prime}$ in the fatigue categories of AASHTO LRFD [8]. Shear studs having $10 \mathrm{~mm}$ diameter and $30 \mathrm{~mm}$ length are used between the steel section and the concrete deck. These connectors are installed in pairs at every $75 \mathrm{~mm}$ along the beam. The transversal distance between the connectors is $40 \mathrm{~mm}$ (Figure 4). In the concrete deck, $6 \mathrm{~mm}$ diameter ribbed bars were used as rebars. These rebars are placed with $75 \mathrm{~mm}$ spacing in both of the longitudinal and transverse directions of the beam in the vertical center of the deck 
(Figure 5). The reinforcement ratio of the concrete deck is approximately $0.8 \%$. The design of these specimens is also used in the study of Gunes et al. [62].

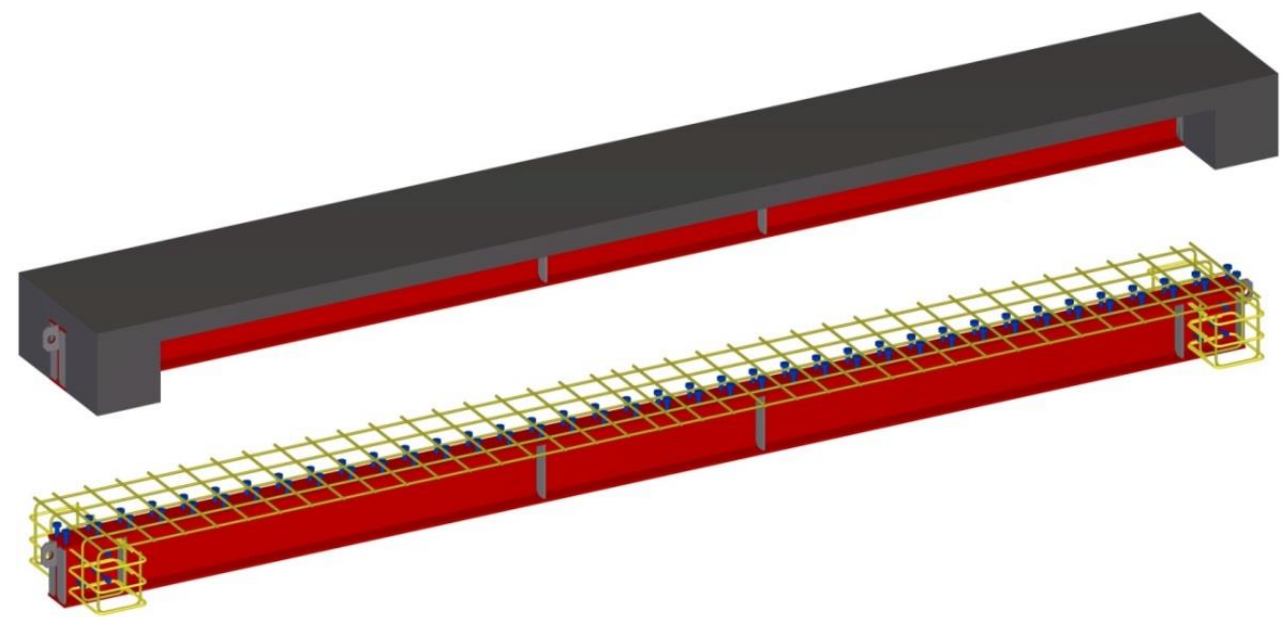

Figure 1. 3D representation and details of the specimens [62].



(a) The section without stiffeners

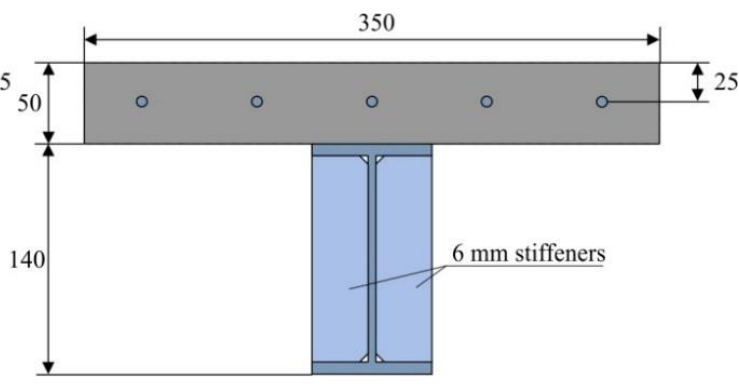

(b) The section with stiffeners

Figure 2. The cross-sectional views of the specimens [62].

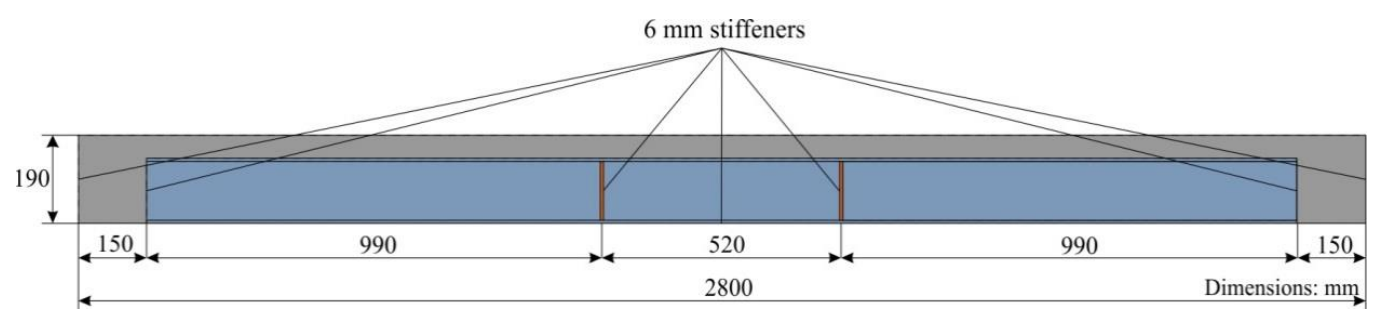

Figure 3. Side view of the specimens [62].

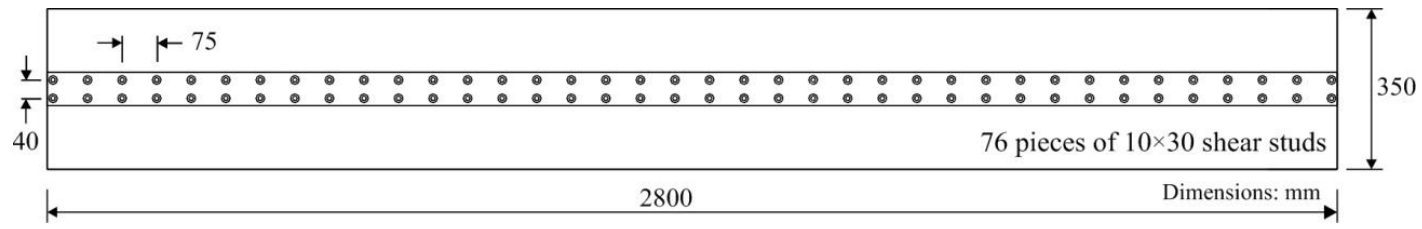

Figure 4. Formation of shear studs [62].

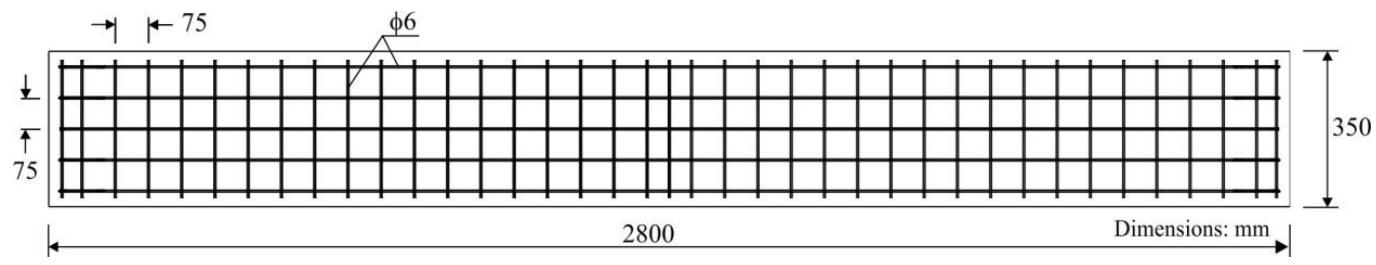

Figure 5. Rebar detailing of the concrete deck [62]. 


\subsection{Fabrication}

The production and preparation of the specimens for the tests are carried out in compliance with the design parameters described above in detail. These processes consist of the following phases: sandblasting of steel section, cutting of steel beam with the desired length, welding of stiffeners and shear studs, production of the concrete deck and support blocks. Firstly, the steel sections are subjected to sandblasting process. After sandblasting, the beams are cut with $2.8 \mathrm{~m}$ length. The transverse stiffeners with $6 \mathrm{~mm}$ thickness are welded on both sides of the web of I-section (one stiffener/each side) at the regions on the concrete blocks at beam supports, and at the regions of load application points (Figure 6). The welding process is performed manually. The weld size (thickness) is $3 \mathrm{~mm}$. Shear studs having $10 \mathrm{~mm}$ diameter and $30 \mathrm{~mm}$ length are welded between the steel section and the concrete deck in order to ensure the combined behavior of this structural system. The welding application is done with a welding machine and a welding gun. The rebars used in the concrete deck is cut with the desired lengths in the workshop and bent according to the design. Prepared rebars are brought to the laboratory and placed in the wooden formworks (Figure 7). Plastic spacers are used to ensure the necessary spacing between the formwork and rebars. Finally, the production stages are completed by pouring concrete into the prepared forms. Some shrinkage cracks are observed on the concrete decks of some specimens after the production.
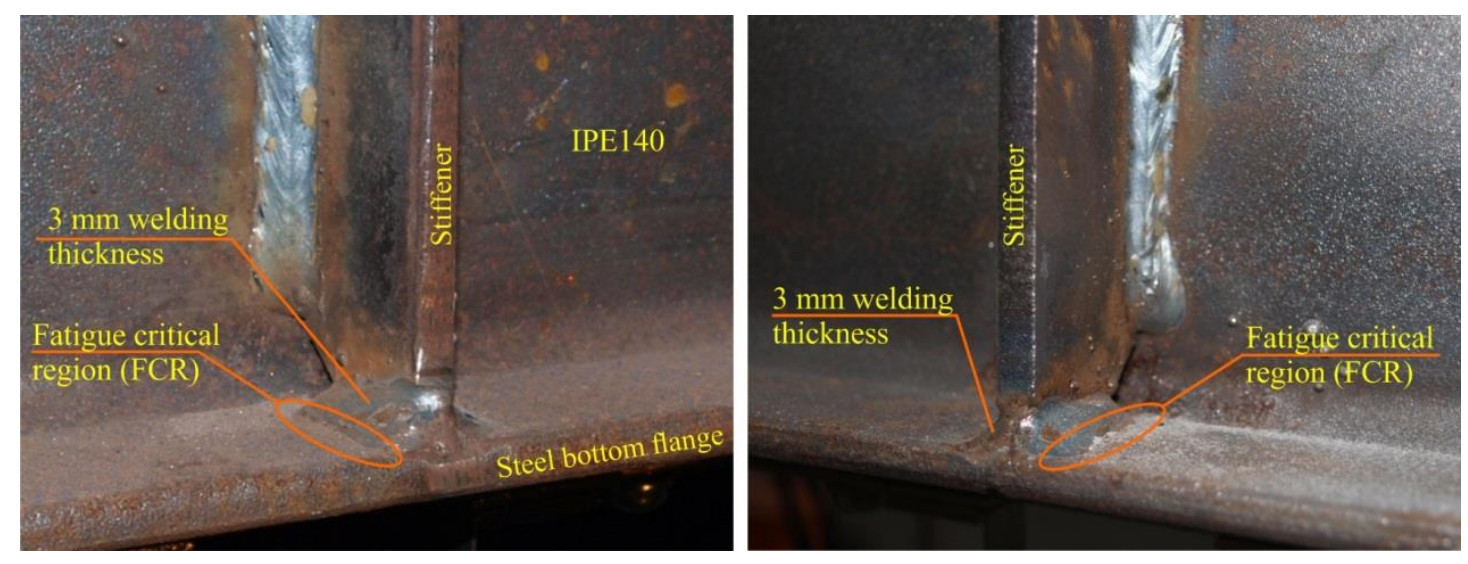

Figure 6. The stiffeners welded to the steel beam (fatigue critical region).
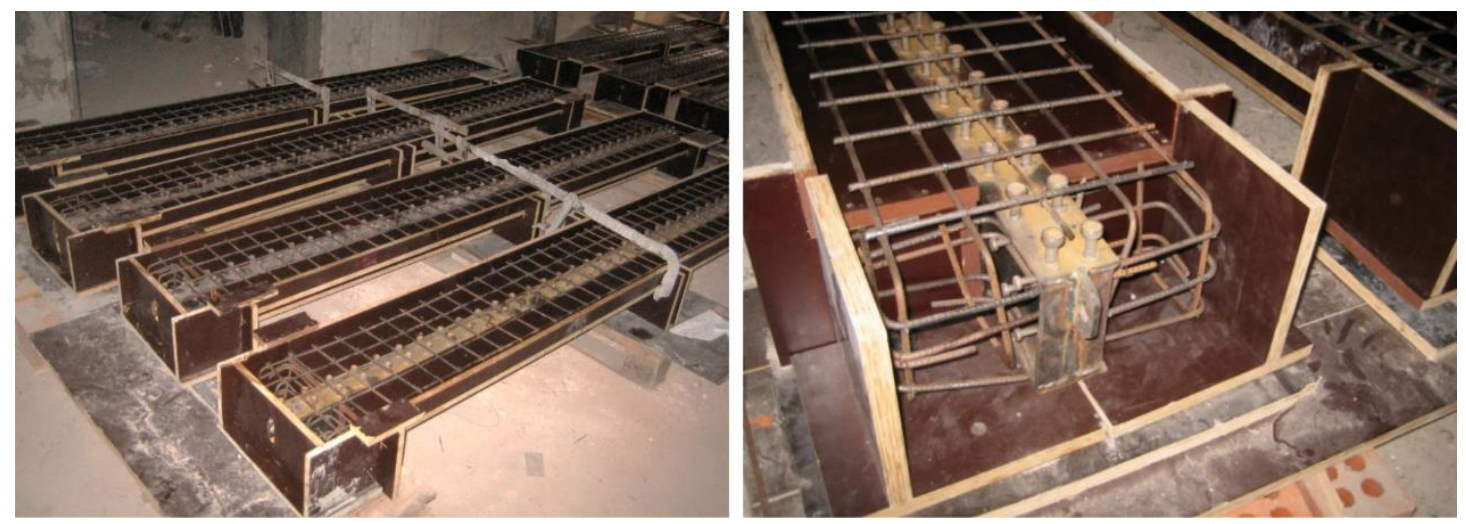

Figure 7. Rebar detailing of the concrete deck.

\subsection{Test Setup and Instrumentation}

MTS 810 type test setup is used in the tests. The used test setup has $\pm 250 \mathrm{kN}$ load capacity, and $\pm 300 \mathrm{~mm}$ displacement capacity. Four-point loading is done in the tests as two of the loads are acting on the supports, and the other two are acting on the load application points (Figure 8). Elastomeric rubber sheets are used in the supports, and between the load distribution beam and the 
concrete deck, in order to prevent local crushing on the deck and to more realistically represent the common practice.

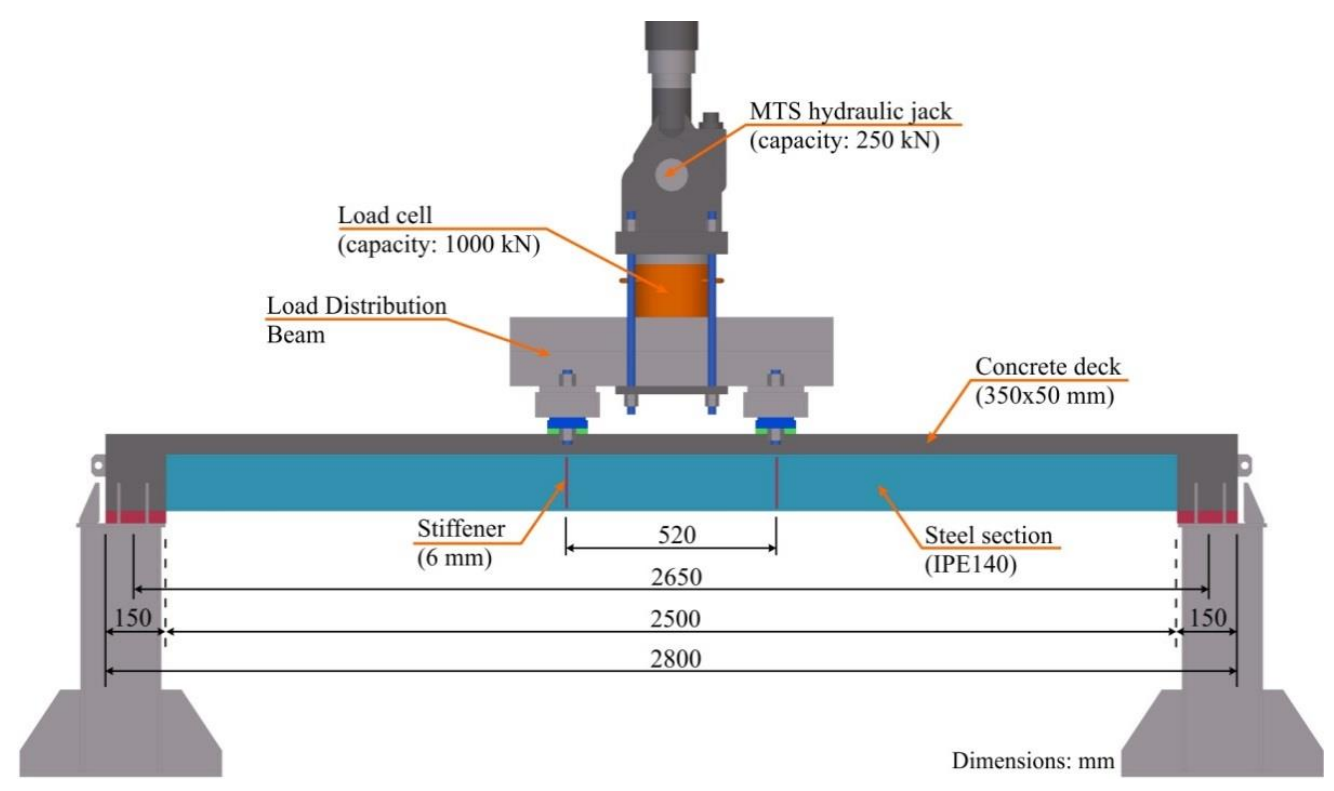

Figure 8. Test specimen and test setup [62].

A load cell having $1000 \mathrm{kN}$ capacity is used between the hydraulic jack and the load distribution beam. Transducers having capacities ranging from 25 to $100 \mathrm{~mm}$ are used to measure the displacement values at different points on the specimen. FLA-6-11-5L type (SS) strain gauge with $6 \mathrm{~mm}$ measuring length is used for the steel part, PL-60-11-3L type (SC) strain gauge with $60 \mathrm{~mm}$ measuring length is used for the reinforced concrete part, along the span and height of the specimen. In addition, PI-5-100 type with a measurement length of $100 \mathrm{~mm}$ and PI-2-50 type with a measurement length of $50 \mathrm{~mm}$ strain gauges are used to measure the average strain values in some regions. The locations of the used measuring instruments on the test specimen are presented in Figure 9. TDS 302 and 303 type static data acquisition systems are used in the tests where monotonic loading was applied. DRA 101-C type dynamic data acquisition system is used in the fatigue tests. MSR abbreviation (midspan region) is used for the region where SS.04 strain gauge is located (Figure 9). FCR abbreviation (fatigue critical regions, see Figure 6) is used for the end regions where the stiffeners are welded to the bottom flange of the steel beam (Figure 9). 


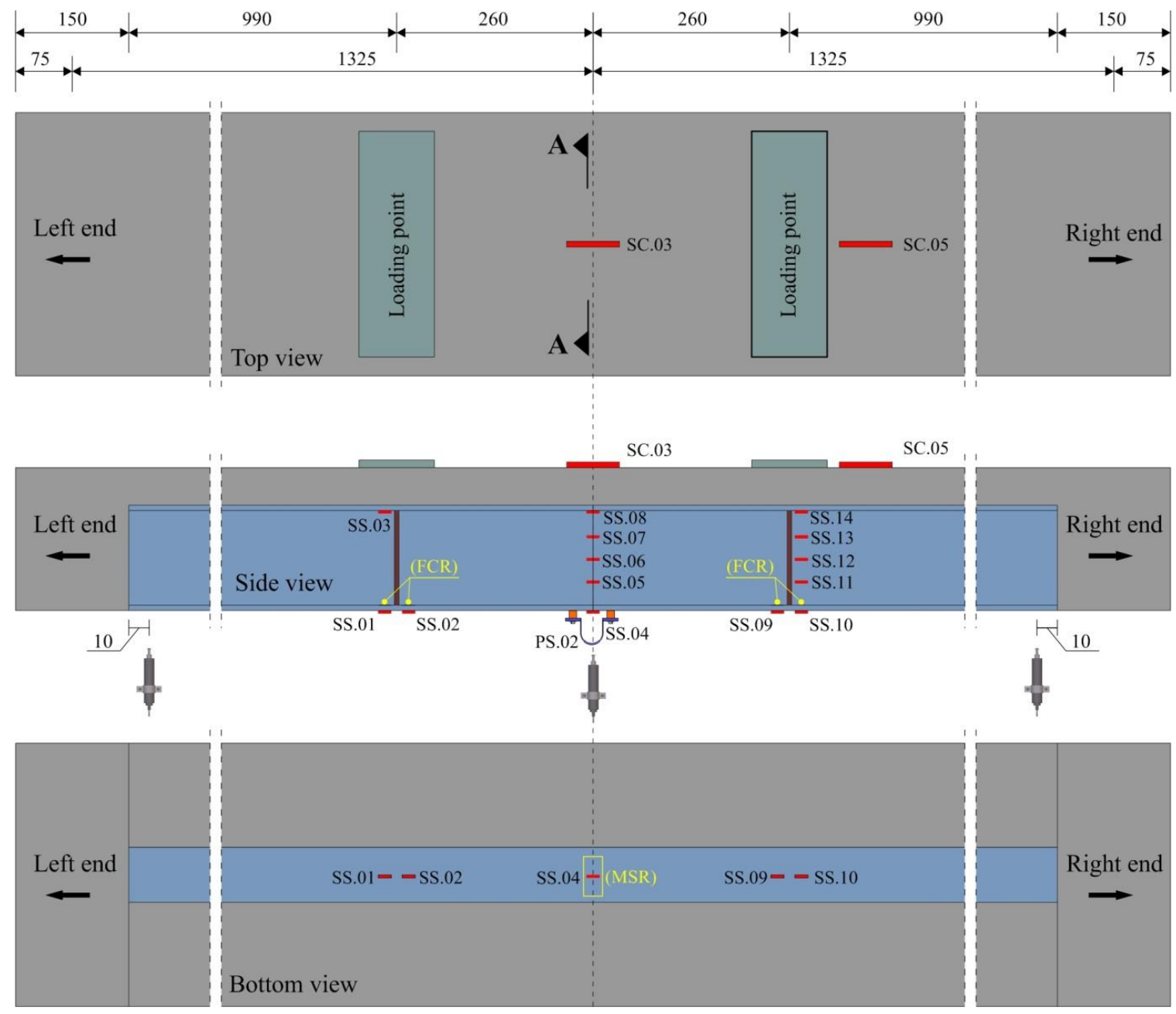

Figure 9. The locations of the measuring instruments on the test specimen.

\subsection{Testing Configuration}

Initially, the specimen GS is statically tested under monotonically increasing displacements. The stiffness, yield strength, ultimate capacity and load-deflection behavior of the specimen are determined by the monotonic test. Then, load-controlled cyclic loads are applied to the specimens GF1, GF2, GF3a, GF3b and GF4. Loading types, number of cycles, the formation of the fatigue cracks and strain ranges formed in MSR and FCR regions during the cyclic loading are presented in Table 2. The yield strain value of the steel is determined considering the data obtained from the material tests $\left(\varepsilon_{y}=0.0019 \mathrm{~mm} / \mathrm{mm}\right)$. The average of the strain ranges in the fatigue critical regions is calculated and presented in order to compare the strain ranges in these regions of the specimens with and without fatigue fractures. Permanent deflection and deformations (strains) occurred in the specimen GF3a at the end of 1,200,000 cycles as a result of accidental overloading. The bottom flange of the steel beam yielded. It is observed that the deflection and strain ranges are changed under the same loading range when cyclic loading is continued. Thus, the specimen is renamed as GF3b after this point, and cyclic loading is continued in order to examine the fatigue behavior of the overloaded beams. Cyclic loading is continued with additional 4,000,000 cycles after overloading.

In the tests of specimens without fatigue fracture, at least 50\% more of the threshold number of cycles $(2,545,927)$ defined in AASHTO LRFD [8] for the fatigue category $C^{\prime}$ is targeted. The strain ranges (amplitudes) of the specimens are determined by targeting $60-30 \%$ of the yield strain in the fatigue critical regions (FCR). The amplitude of the other specimens is determined according to the presence of fatigue fracture during the test process. 
Table 2. Test matrix.

\begin{tabular}{cccccc}
\hline Specimen & $\begin{array}{c}\text { Loading } \\
\text { Type }\end{array}$ & $\begin{array}{c}\text { Number of } \\
\text { Cycles }\end{array}$ & $\begin{array}{c}\text { Fatigue } \\
\text { Crack }\end{array}$ & $\begin{array}{c}\text { Strain Range } \\
\text { (MSR) }\end{array}$ & $\begin{array}{c}\text { Average Strain } \\
\text { Range (FCR) }\end{array}$ \\
\hline GS & Monotonic & - & - & - & - \\
GF1 & Cyclic & 407,000 & Yes & $0.68 \varepsilon_{\mathrm{y}}$ & $0.57 \varepsilon_{\mathrm{y}}$ \\
GF2 & Cyclic & 584,800 & Yes & $0.57 \varepsilon_{\mathrm{y}}$ & $0.48 \varepsilon_{\mathrm{y}}$ \\
GF3a $^{1}$ & Cyclic & $1,200,000$ & No & $0.48 \varepsilon_{\mathrm{y}}$ & $0.42 \varepsilon_{\mathrm{y}}$ \\
GF3b ${ }^{1}$ & Cyclic & $4,000,000$ & No & $0.42 \varepsilon_{\mathrm{y}}$ & $0.37 \varepsilon_{\mathrm{y}}$ \\
GF4 & Cyclic & $4,438,000$ & No & $0.39 \varepsilon_{\mathrm{y}}$ & $0.32 \varepsilon_{\mathrm{y}}$ \\
\hline
\end{tabular}

${ }^{1}$ GF3a specimen is renamed as GF3b at the end of 1,200,000 load cycles.

\section{Results}

\subsection{Specimen GS}

In Figure 10a, load-deflection behavior of specimen GS is presented. In this specimen, yielding of steel beam occurred at $70.00 \mathrm{kN}$ load and $12.54 \mathrm{~mm}$ midspan deflection values. The yield load is defined as the total load when the strain value is reached under the bottom flange of the steel beam. Crushing of concrete in the deck occurred at $97.00 \mathrm{kN}$ load and $46.92 \mathrm{~mm}$ midspan deflection values, and the specimen reached its ultimate capacity. When $96.66 \mathrm{kN}$ load and $47.34 \mathrm{~mm}$ midspan deflection values are reached in the midspan, the rebars in the concrete deck are buckled, and the specimen failed by losing its capacity. The total strength loss is calculated about $25 \%$ with the crushing of concrete and buckling of rebars in the deck. The load-strain curves of the section in the midspan are shown in Figure 10b. The initial neutral axis of the specimen was between the SS-06 and SS-07 strain gauges. As the load level increased, the neutral axis shifted into the region between the SS-07 and SS-08 strain gauges. The maximum strain occurred on the concrete deck is obtained at $P=97.00 \mathrm{kN}$ and $\delta=33.62 \mathrm{~mm}$ values, as $-0.0030 \mathrm{~mm} / \mathrm{mm}$. Midspan deflection, crushing of concrete and buckling of rebars occurred at the end of the test of the specimen GS are presented in Figure 11.

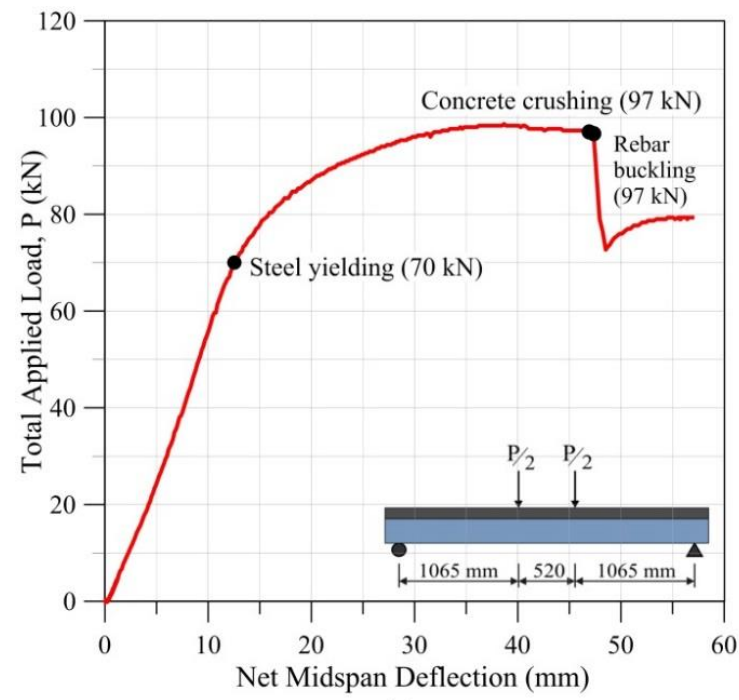

(a)

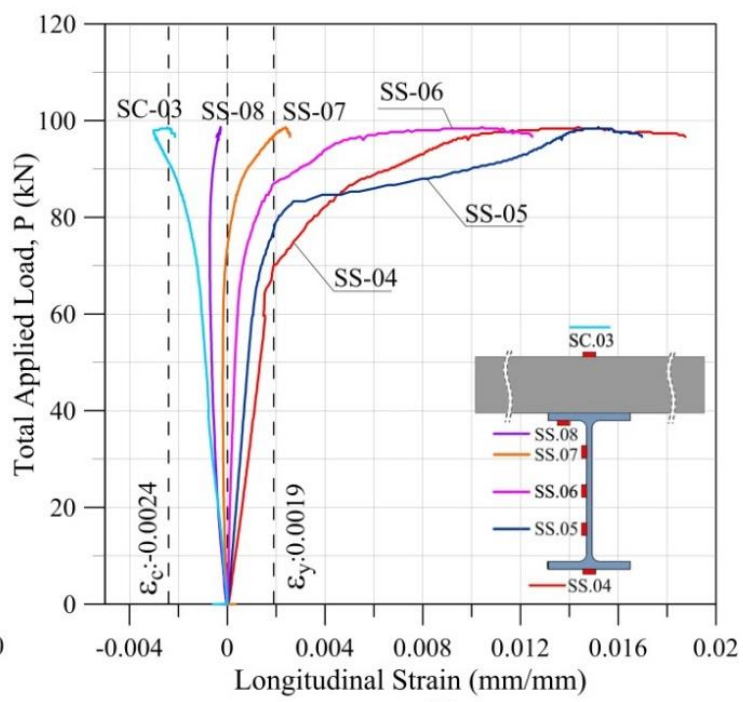

(b)

Figure 10. Curves of the specimen GS: (a) load-deflection; (b) load-strain. 


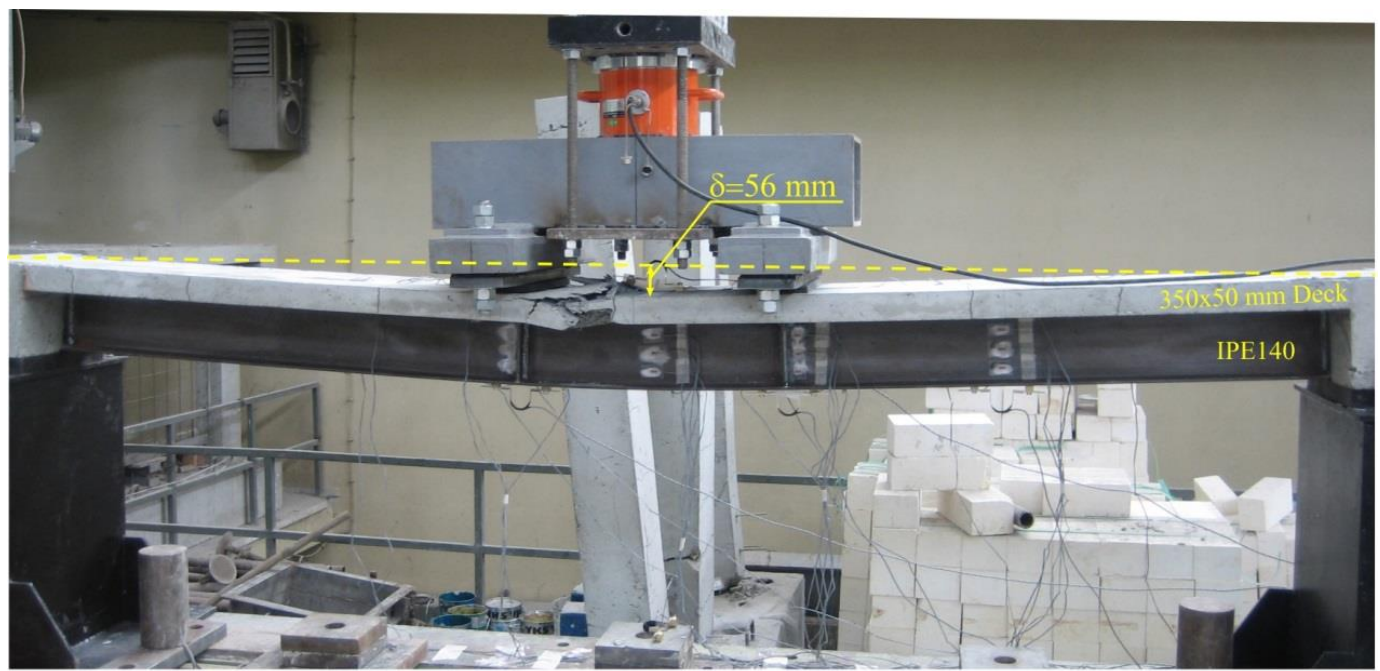

(a) The specimen's view at the end of the test

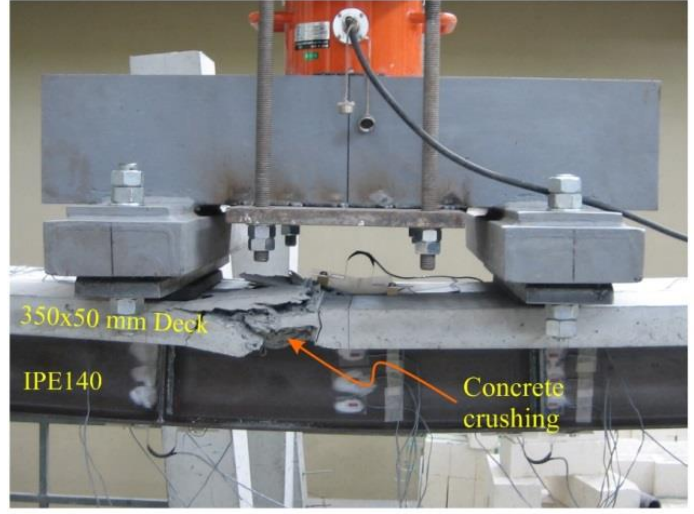

(b) Crushing of concrete in the deck

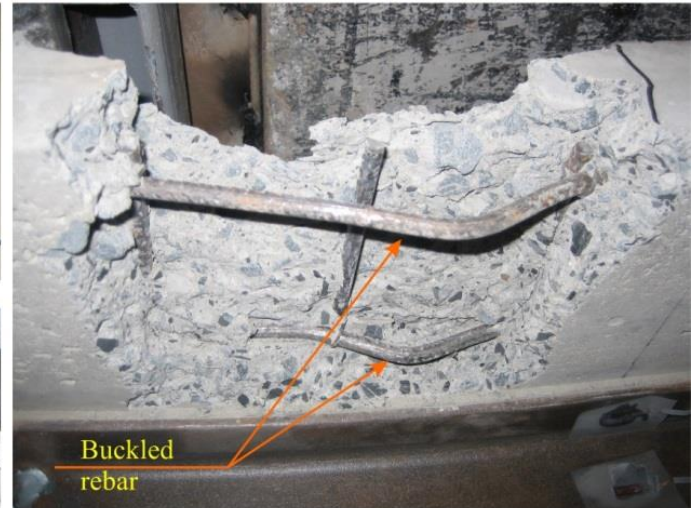

(c) Buckling of the rebar

Figure 11. Midspan deflection, crushing of concrete and buckling of rebars at the end of test of the specimen GS.

\subsection{Specimen GF1}

Cyclic loading is applied to the specimen GF1 with a minimum of $0.67 \mathrm{kN}$, a maximum of $50.64 \mathrm{kN}$, and a loading rate of $0.9 \mathrm{~Hz}$. Under these loads, an average stress range of $218 \mathrm{MPa}$ is observed on fatigue critical regions. A crack occurred at the number of 403,000 load cycles on the bottom flange of the steel beam (left edge of the stiffener on the right). As this crack propagated through the bottom flange and height of the web, the specimen lost its capacity at the end of 407,000 load cycles and collapsed. Midspan deflection, fatigue crack and fatigue fracture occurred at the end of the test of the specimen GF1 are presented in Figure 12.

The variation of the deflection range $(\Delta \delta)$ during cyclic loading, and the maximum and minimum deflections $\left(\delta_{\max }, \delta_{\min }\right)$ obtained are shown in Figure 13a. From the beginning of the test until 403,000 cycles just before the formation of the crack, the maximum deflection, $\delta_{\max }$, is increased from $9.35 \mathrm{~mm}$ to $9.74 \mathrm{~mm}$, and the deflection range, $\Delta \delta$, is increased from $8.89 \mathrm{~mm}$ to $9.14 \mathrm{~mm}$. The increase in the maximum deflection and the deflection range is continued similarly through the test. The maximum deflection is increased to $\delta_{\max }=10.50 \mathrm{~mm}$, and the deflection range is increased to $\Delta \delta=9.23 \mathrm{~mm}$, at 406,800 cycles just before the collapse of the specimen. The permanent deflection of the specimen is found as $\delta=42.94 \mathrm{~mm}$ at the end of the fatigue failure. The normalized stiffness of the specimen decreased to 0.96 just before the formation of the crack (Figure 13b). 


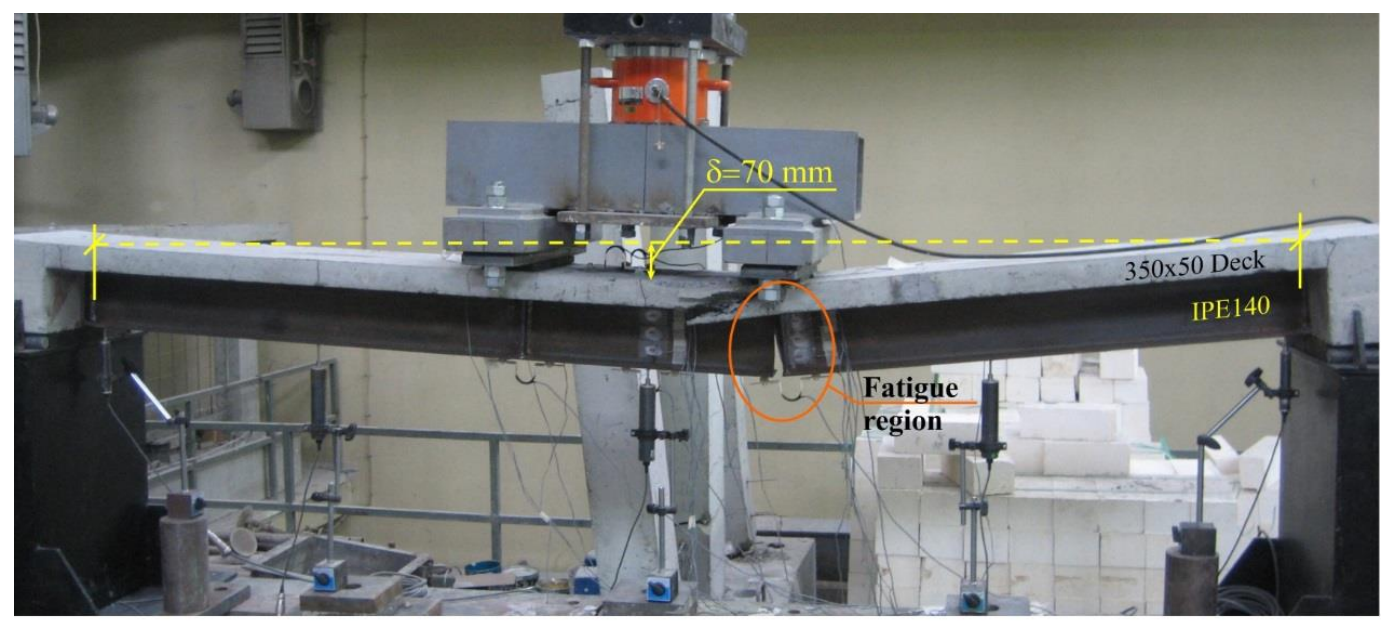

(a) The specimen's view at the end of the test



(b) Fatigue crack

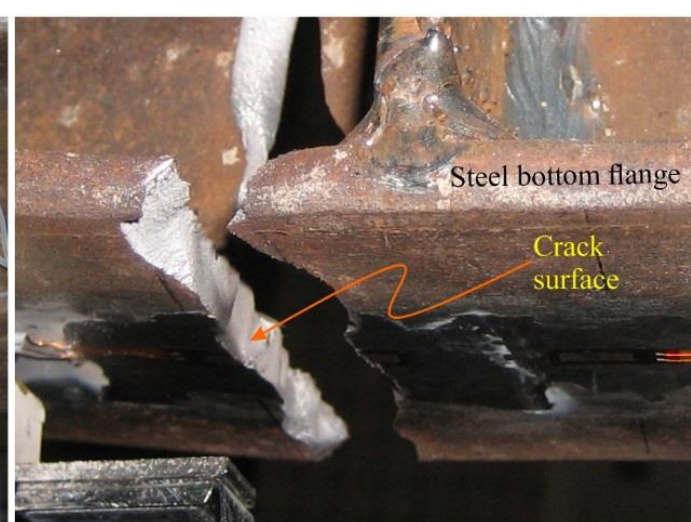

(c) Crack surface

Figure 12. Midspan deflection, fatigue crack and crack surface at the end of test of the specimen GF1.

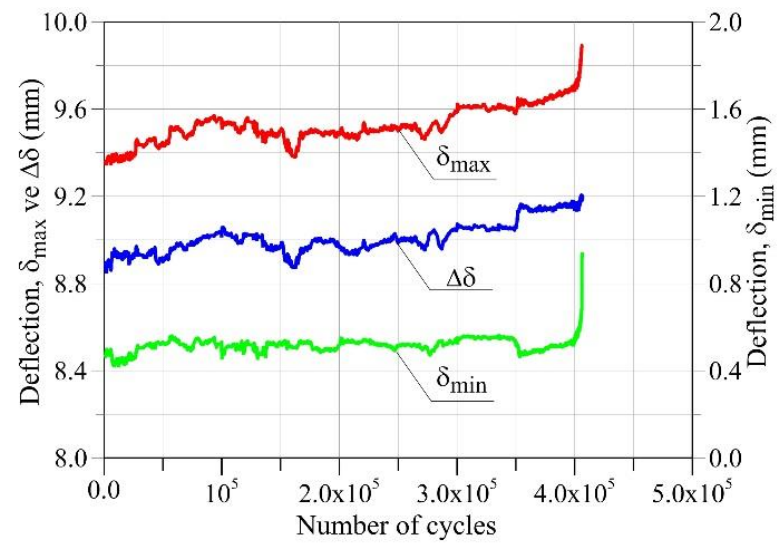

(a) Deflection degradation

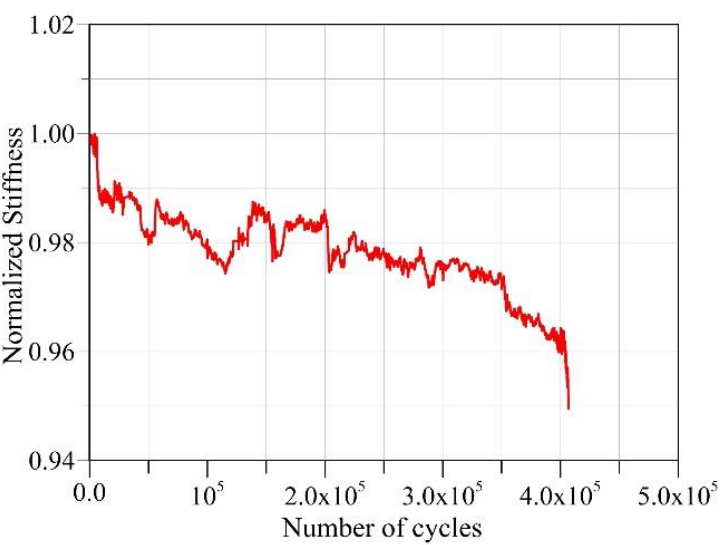

(b) Stiffness degradation

Figure 13. The change in deflection and stiffness of the specimen GF1 during cyclic loading.

In midspan and stiffener regions, the variation of the strain range formed on the steel bottom flange during cyclic loading is shown in Figure 14. Up to 295,000 cycles, the strain range in these regions varied from 1130 to $1300 \mu \varepsilon$. No significant change is observed on the strain range up to this number of cycles. After this number of cycles, the values obtained from the strain gauge SS.10 started to increase unlike the others, and this trend continued increasingly. At 360,000 cycles, the values obtained from the strain gauge SS.09 increased rapidly and exceeded the values obtained from SS.10 at 400,700 cycles. 
At 403,000 cycles, a fatigue crack is formed on the location of the strain gauge SS.09. This fatigue crack is formed at the center of the strain gauge SS.09. After this point, the crack is propagated to the edges of the bottom flange, and the bottom flange is completely cracked. At the end of 407,000 cycles, the fatigue failure occurred by the propagation of the crack through the height of the web, and the specimen lost its capacity.



Figure 14. The change in the strain range of the specimen GF1 during cyclic loading.

\subsection{Specimen GF2}

Cyclic loading is applied to the specimen GF2 with a minimum of $0.8 \mathrm{kN}$, a maximum of $42 \mathrm{kN}$, and a loading rate of $1.2 \mathrm{~Hz}$. Under these loads, an average stress range of $182 \mathrm{MPa}$ is observed on fatigue critical regions. A crack occurred at 572,400 cycles on the bottom flange of the steel beam (left edge of the stiffener on the left). As this crack propagated through the bottom flange and height of the web, the specimen lost its capacity at the end of 584,800 cycles and collapsed. This fatigue crack and its propagation is shown in Figure 15.

The variation of the deflection range $(\Delta \delta)$ during cyclic loading, and the maximum and minimum deflections $\left(\delta_{\max }, \delta_{\min }\right)$ obtained are shown in Figure 16a. From the beginning of the test until 572,250 cycles just before the formation of the crack, the maximum deflection, $\delta_{\max }$, is increased from $8.08 \mathrm{~mm}$ to $8.13 \mathrm{~mm}$, and the deflection range, $\Delta \delta$, is increased from $7.69 \mathrm{~mm}$ to $7.88 \mathrm{~mm}$. No significant increase is observed on the values related to the maximum deflection and deflection range up to this number of cycles. With the formation of the fatigue crack, the values increased rapidly, and the maximum deflection value is increased to $\delta_{\max }=9.54 \mathrm{~mm}$ and the deflection range is increased to $\Delta \delta=7.96 \mathrm{~mm}$ at the end of 584,200 cycles just before the collapse of the specimen. The permanent deflection of the specimen is found as $\delta=37.90 \mathrm{~mm}$ at the end of the test. There was no significant reduction in the normalized stiffness of the specimen until the formation of the crack. The stiffness value of the specimen decreased to 0.98 just before the formation of the crack. After the crack, the stiffness value also decreased rapidly to 0.94 just before the collapse of the specimen (Figure 16b).

In midspan and stiffener regions, the variation of the strain range formed on the steel bottom flange during cyclic loading is shown in Figure 17. Up to 400,000 cycles when the fatigue crack symptoms occur, the strain range in these regions varied from 940 to $1090 \mu \varepsilon$. No significant change is observed on the strain range up to this number of cycles. After this number of cycles, the values obtained from the strain gauges SS.01 and SS.02 under the left stiffener are started to differentiate than others. While the values from SS.02 started to increase, the values from SS.01 began to decrease. This situation indicates the onset of the fatigue crack. The values continued in this pattern up to about 550,000 cycles. After this point, the values obtained from the strain gauge SS.01 suddenly started to increase, and after a 
while, exceeded the values obtained from the strain gauge SS.02. At the end of 572,400 cycles, the first fatigue crack is formed at the edge of the bottom flange. This crack is propagated on the bottom flange, passing through the center of the region that strain gauge SS.01 is located. At the end of 584,800 cycles, the fatigue failure occurred by the propagation of the crack through the height of the web, and the specimen lost its capacity.

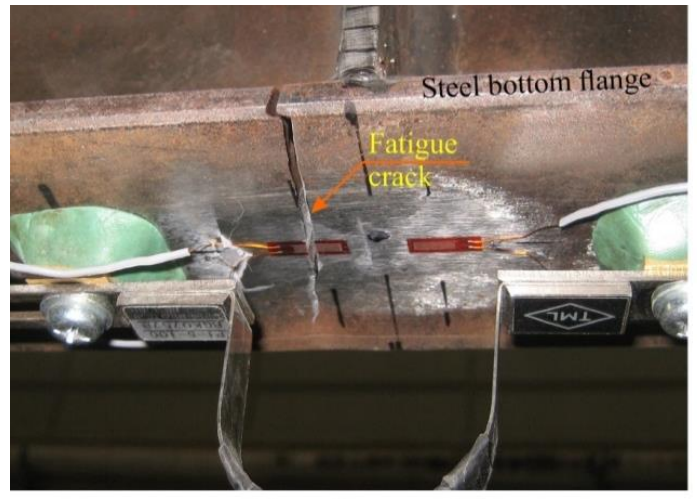

(a) Fatigue crack

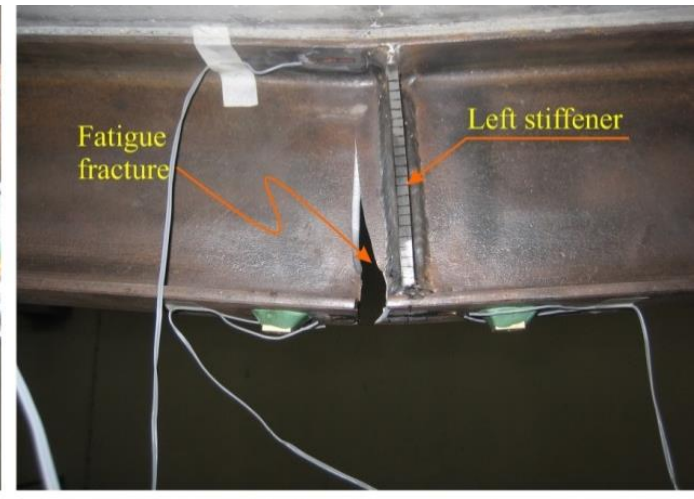

(b) Crack propagation

Figure 15. Fatigue crack and crack propagation on the specimen GF2.

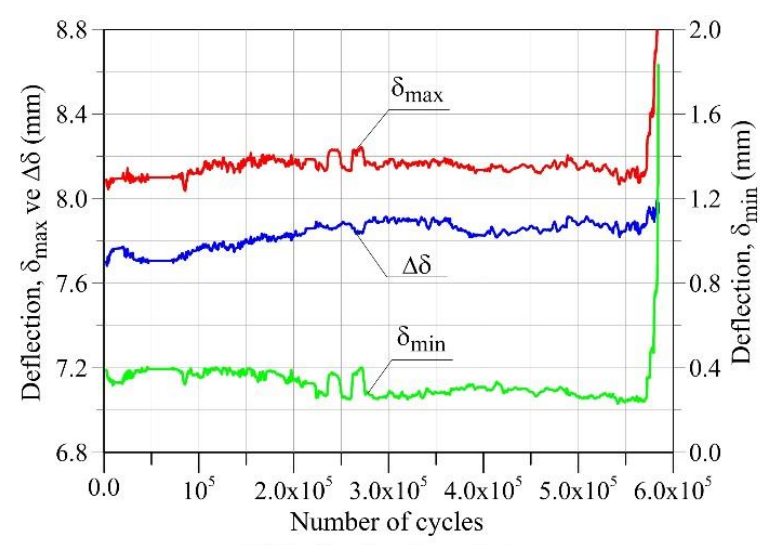

(a) Deflection degradation

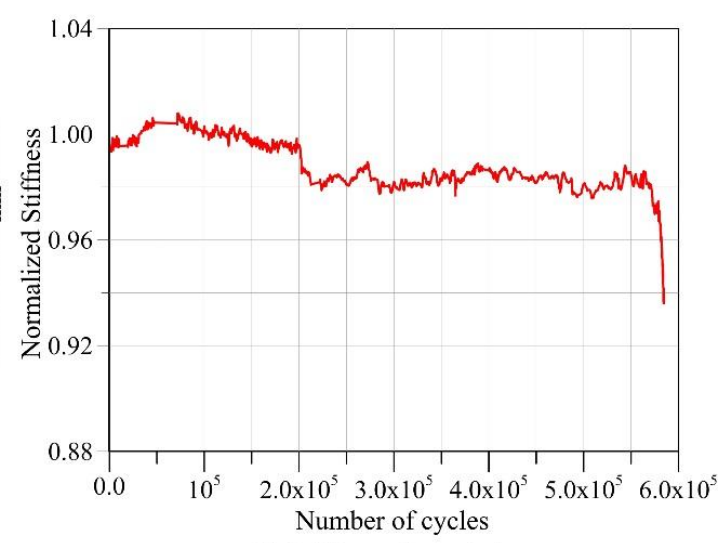

(b) Stiffness degradation

Figure 16. The change in deflection and stiffness of the specimen GF2 during cyclic loading.

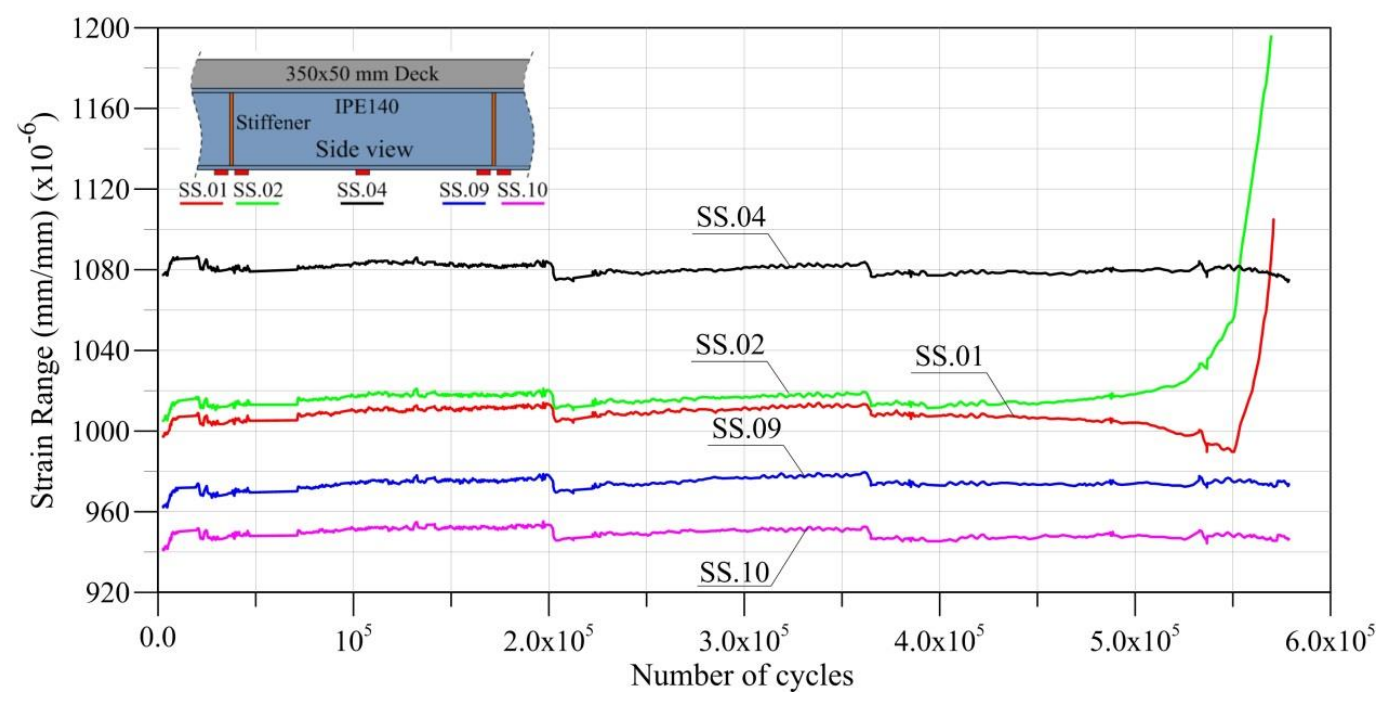

Figure 17. The change in the strain range of the specimen GF2 during cyclic loading. 


\subsection{Specimen GF3a}

Cyclic loading is applied to the specimen GF3a with a minimum of $0.7 \mathrm{kN}$, a maximum of $35.1 \mathrm{kN}$, and a loading rate of $1.8 \mathrm{~Hz}$. Under these loads, an average stress range of $159 \mathrm{MPa}$ is observed on fatigue critical regions. At the end of 1,200,000 cycles, no fatigue cracks or collapse are observed and the specimen did not collapse due to the fatigue. The variation of the deflection range $(\Delta \delta)$ during cyclic loading, and the maximum and minimum deflections $\left(\delta_{\max }, \delta_{\min }\right)$ obtained are shown in Figure 18a. The maximum deflection and deflection range increased throughout the test. However, the increase rates were not at a significant level. From the beginning until the termination of the test, the maximum deflection, $\delta_{\max }$, is increased from $7.35 \mathrm{~mm}$ to $7.60 \mathrm{~mm}$, and the deflection range, $\Delta \delta$, is increased from $6.80 \mathrm{~mm}$ to $7.22 \mathrm{~mm}$. The normalized stiffness of the specimen decreased throughout the test to 0.94 (Figure 18b).

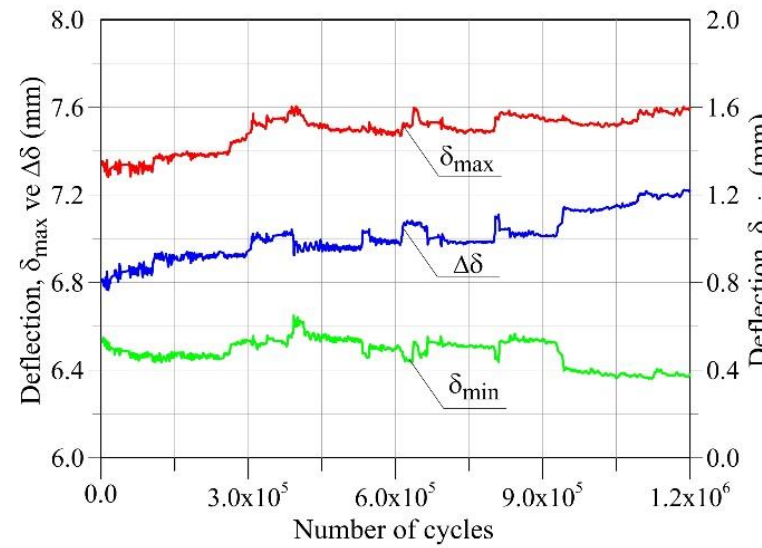

(a) Deflection degradation

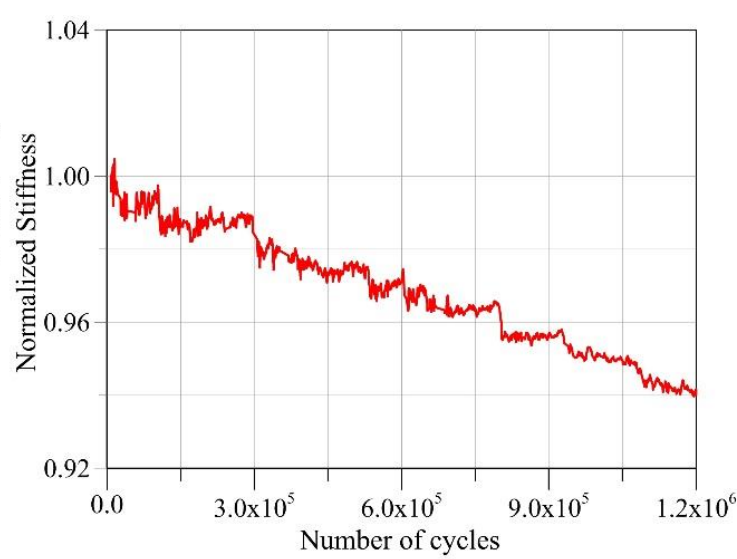

(b) Stiffness degradation

Figure 18. The change in deflection and stiffness of the specimen GF3a during cyclic loading.

In midspan and stiffener regions, the variation of the strain range formed on the steel bottom flange during cyclic loading is shown in Figure 19. When the strain range-number of cycles curves are viewed, it is seen that the values of strain range varied between 830-930 $\mu \varepsilon$. No significant change is observed in the strain range. The strain ranges in these regions continued on a similar trend throughout the test. This behavior shows that formation of the fatigue cracks has not been started until this stage.

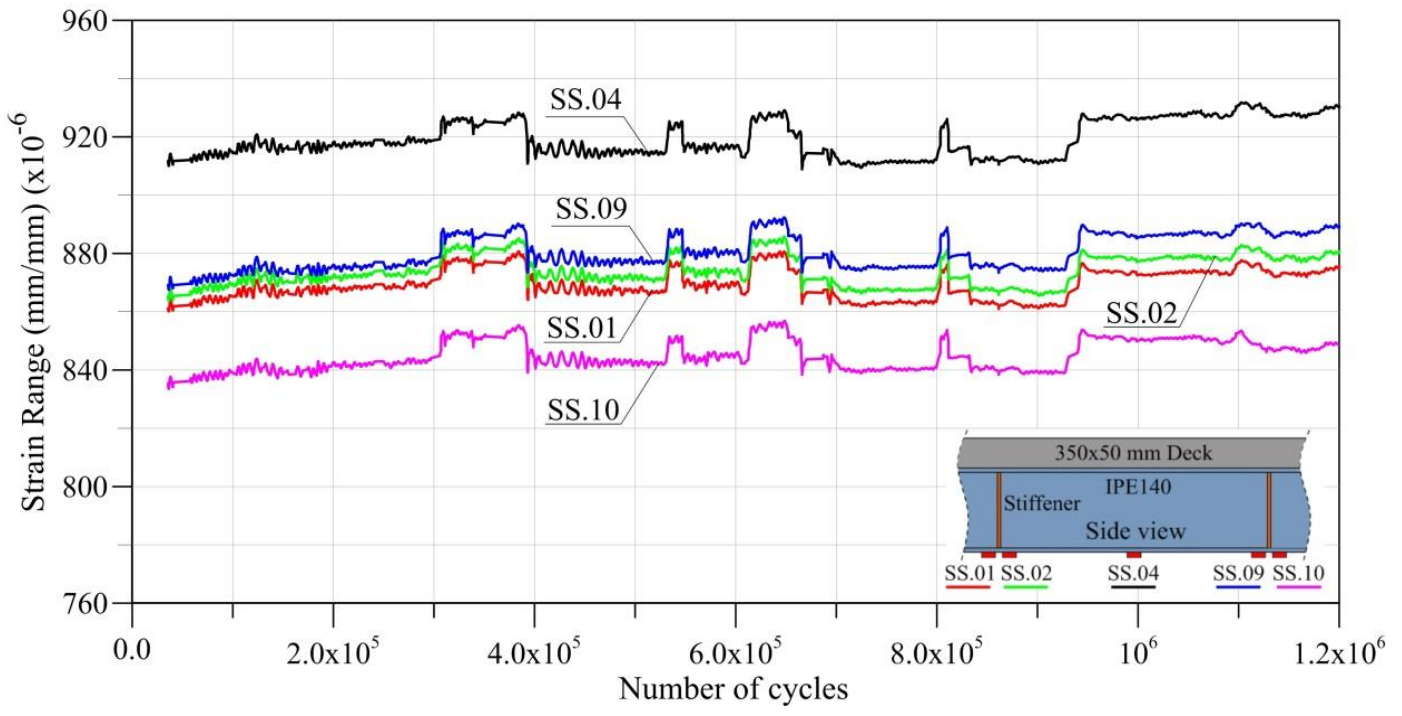

Figure 19. The change in the strain range of the specimen GF3a during cyclic loading. 
At the end of 1,200,000 cycles, $\delta=31.52 \mathrm{~mm}$ of permanent deflection occurred as a result of accidental overloading of the specimen GF3a. In addition, permanent strains of 2367, 791, 14459, 960 and $1883 \mu \varepsilon$ occurred on the strain gauges SS.01, SS.02, SS.04, SS.09 and SS.10, respectively. After this point, the specimen is considered as a new specimen (GF3b), which is yielded due to the overloading. Cyclic loading is continued to examine the fatigue behavior of the beams in this situation.

\subsection{Specimen GF3b}

Cyclic loading is applied to the specimen GF3b with 400,000 cycles, a loading range of $33.87 \mathrm{kN}$, and a loading rate of $1.8 \mathrm{~Hz}$. Although the applied loading range was almost the same as the GF3a specimen, the deflections and the strain range were reduced. At the end of 1,200,000 cycles, the deflection range of GF3a was $\Delta \delta=7.22 \mathrm{~mm}$. On the other hand, the deflection range of GF3b at the same loading range was $\Delta \delta=5.24 \mathrm{~mm}$. Similar differences are also observed on the strain ranges. In midspan and stiffener regions of specimen GF3a, at the end of 1,200,000 cycles, the strain range obtained from the strain gauges SS.01, SS.02, SS.04, SS.09 and SS.10 were 873, 879, 930, 890 and $849 \mu \varepsilon$, respectively. On the other hand, for the specimen GF3b at the same loading range, the strain range obtained from the same strain gauges were $767,769,792,754$ and $713 \mu \varepsilon$, respectively. The average stress range in the fatigue critical regions (FCR) of the specimen GF3a was $159 \mathrm{MPa}$, while the average stress range at the same loading range in the specimen GF3b was $142 \mathrm{MPa}$.

Although the loading range remained constant throughout the test of the specimen GF3b, the increase in deflection and strain ranges were more than the other specimens. If the deflection and strain ranges of $1,200,000$ and $5,200,000$ cycles are compared, it can be said that $\Delta \delta=5.24 \mathrm{~mm}$ deflection range is increased to $\Delta \delta=5.61 \mathrm{~mm}$, and 713 792 $\mu \varepsilon$ strain range is increased to $740 \sim 807 \mu \varepsilon$ by $30 \mu \varepsilon$ of an increase rate (Figures 20a and 21). Accordingly, as can be seen in Figure 20b, the normalized stiffness of the specimen is decreased to 0.94 of its stiffness at $1,200,000$ cycles. The strain ranges in all regions continued on a similar trend with respect to each other throughout the test. This situation indicates that there was no onset of fatigue in the specimen. At the end of the test, the permanent deflection value is increased from $\delta=31.52 \mathrm{~mm}$ to $\delta=32.28 \mathrm{~mm}$ by $0.76 \mathrm{~mm}$. Also, the permanent strains on the strain gauges SS.01, SS.02, SS.04, SS.09 and SS.10 are increased to 2498, 930, 14544, 1190 and $1984 \mu \varepsilon$ values by $131,139,85,130$ and $101 \mu \varepsilon$, respectively.

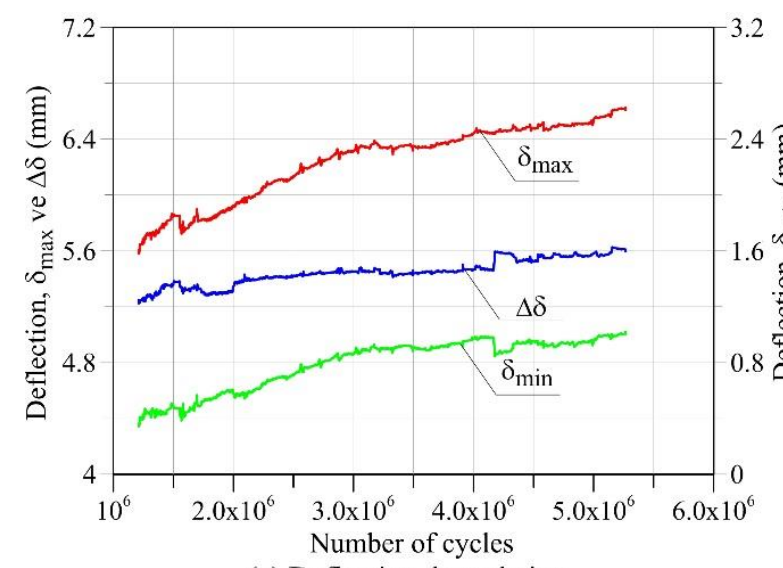

(a) Deflection degradation

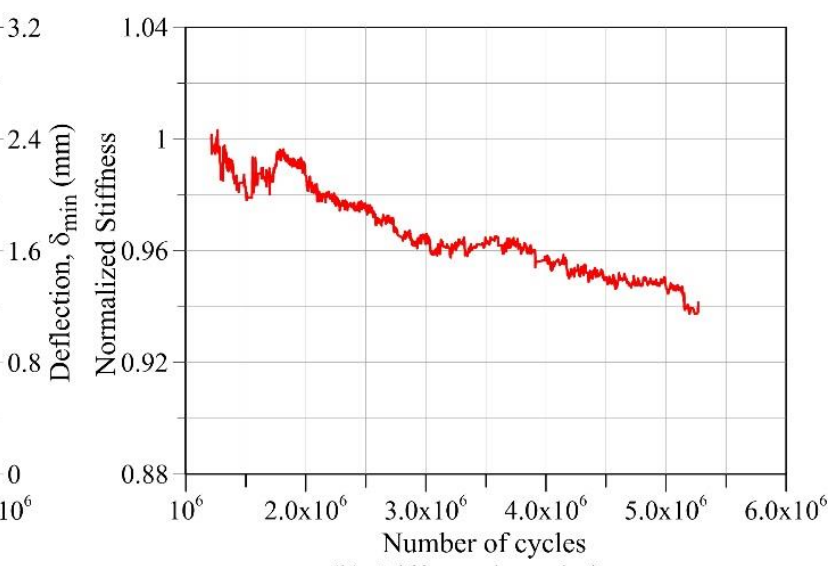

(b) Stiffness degradation

Figure 20. The change in deflection and stiffness of the specimen GF3b during cyclic loading. 


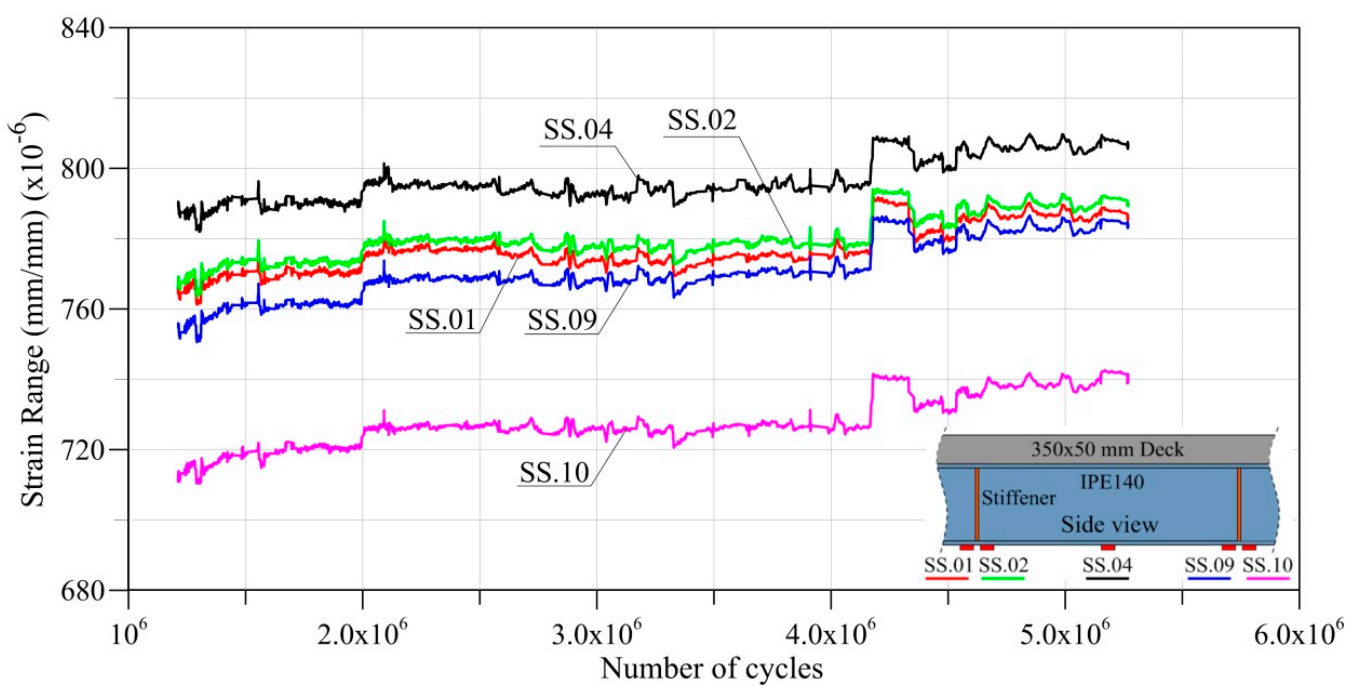

Figure 21. The change in the strain range of the specimen GF3b during cyclic loading.

\subsection{Specimen GF4}

Cyclic loading is applied to the specimen GF4 with a minimum of $0.8 \mathrm{kN}$, a maximum of $26.8 \mathrm{kN}$, and a loading rate of $2.5 \mathrm{~Hz}$. Under these loads, an average stress range of $121 \mathrm{MPa}$ is observed on fatigue critical regions. No fatigue cracks are observed at the end of 4,438,000 cycles. The variation of the deflection range $(\Delta \delta)$ during cyclic loading, and the maximum and minimum deflections $\left(\delta_{\max }\right.$, $\left.\delta_{\min }\right)$ obtained are shown in Figure 22a. In the related graph, the maximum deflection values showed fluctuations throughout the test. The maximum deflection $\left(\delta_{\max }\right)$, which was $5.90 \mathrm{~mm}$ at the beginning of the test, increased to $6.08 \mathrm{~mm}$ during the test and measured as $5.93 \mathrm{~mm}$ at the end of the test. The deflection range $(\Delta \delta)$, which was $5.40 \mathrm{~mm}$ at the beginning of the test, increased to $5.70 \mathrm{~mm}$ at $3,250,000$ cycles. After this point, no significant change is observed on the deflection range until the end of the test. The normalized stiffness of the specimen decreased to 0.95 until 3,250,000 cycles and remained approximately the same after this point (Figure 22b).

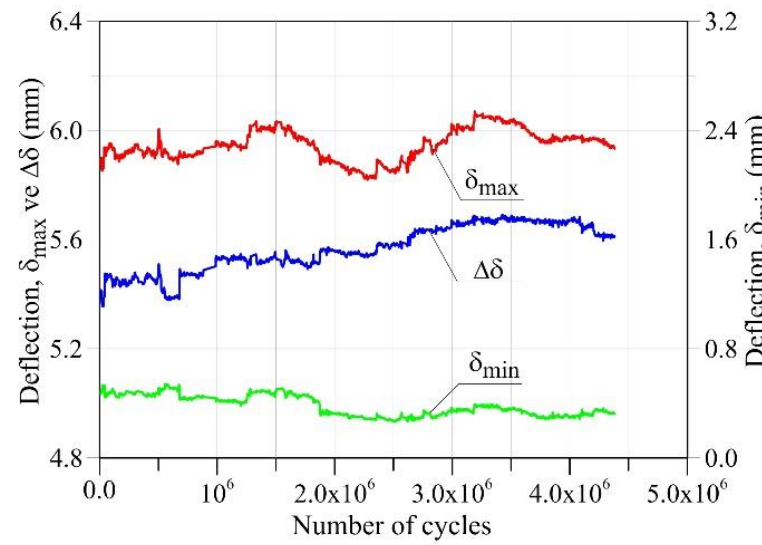

(a) Deflection degradation

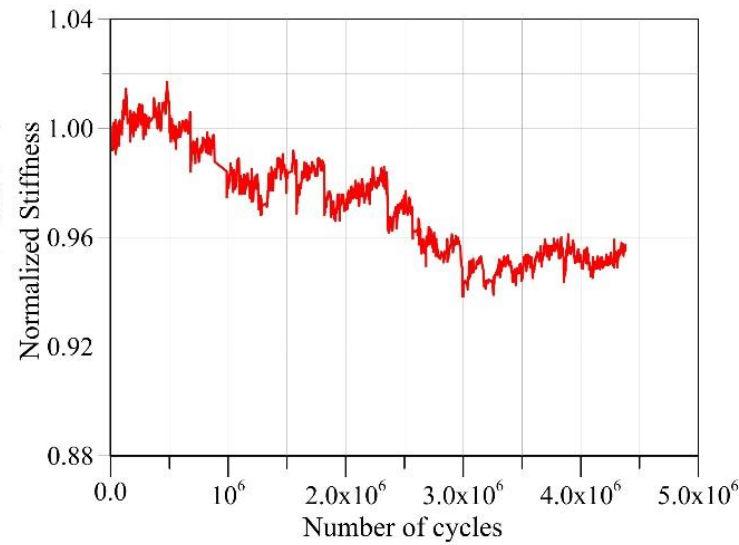

(b) Stiffness degradation

Figure 22. The change in deflection and stiffness of the specimen GF4 during cyclic loading.

In midspan and stiffener regions, the variation of the strain range formed on the steel bottom flange during cyclic loading is shown in Figure 23. The stress ranges are varied from $630 \mu \varepsilon$ to $750 \mu \varepsilon$ in these regions throughout the test, and no significant change is observed on the stress ranges. The maximum increase in the stress ranges is measured as $25 \mu \varepsilon$ with respect to the beginning of the test. The strain ranges in all regions continued on a similar trend with respect to each other throughout the test. This situation means that there was no onset of fatigue failure and crack in the specimen. 


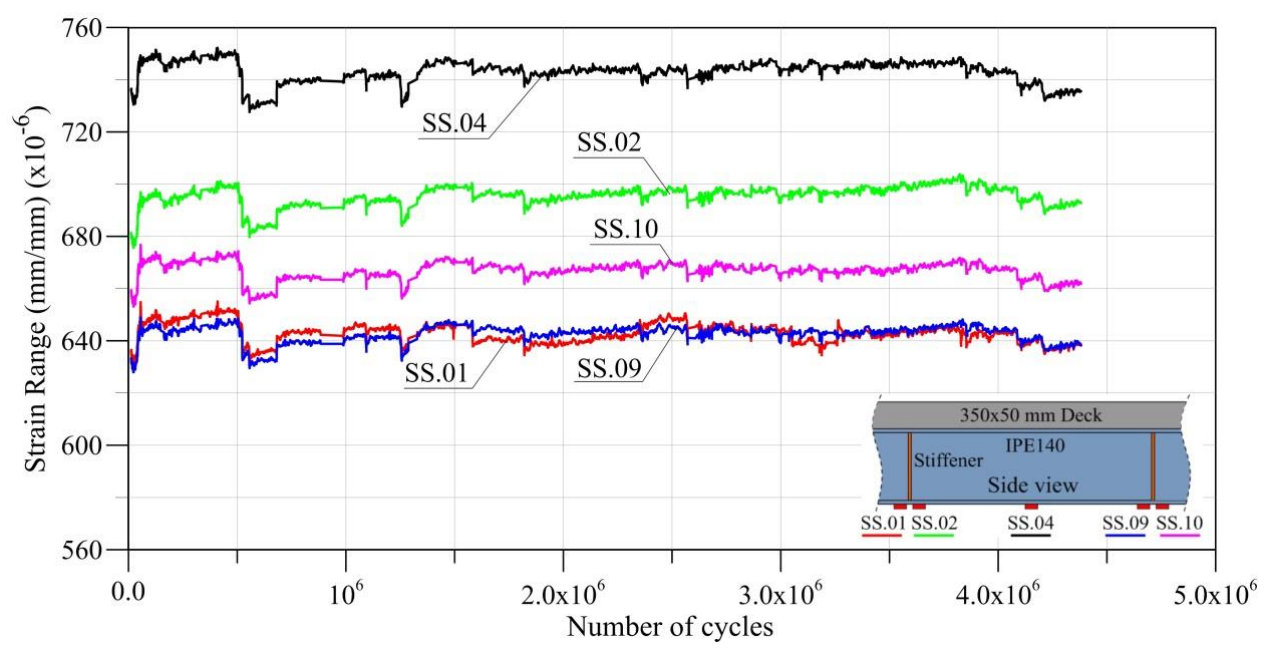

Figure 23. The change in the strain range of the specimen GF4 during cyclic loading.

\section{Discussion}

The loading properties and the strain and stress ranges formed on midspan regions (MSR) (under the bottom flange) are given in Table 3. As can be seen in the table, cyclic loads are applied to the specimens with various loading rates varying between 0.9 and $2.5 \mathrm{~Hz}$, and various loading ranges varying between 49.96 and $26.00 \mathrm{kN}$. Under the cyclic loading, the ratio of strain range to yield strain varies between $68-39 \%$.

Table 3. Strain and stress ranges in MSR regions.

\begin{tabular}{cccccc}
\hline Specimen & $\begin{array}{c}\text { Loading } \\
\text { Rate (Hz) }\end{array}$ & $\begin{array}{c}\text { Loading } \\
\text { Range (kN) }\end{array}$ & $\begin{array}{c}\text { Strain Range } \\
(\mathbf{S S . 0 4 )}(\boldsymbol{\mu \varepsilon})\end{array}$ & $\begin{array}{c}\text { Strain Range/Yield } \\
\text { Strain }(\%)\end{array}$ & $\begin{array}{c}\text { Stress Range } \\
(\mathbf{M P a})\end{array}$ \\
\hline GF1 & 0.9 & 49.96 & 1283 & 68 & 257 \\
GF2 & 1.2 & 41.20 & 1078 & 57 & 216 \\
GF3a ${ }^{1}$ & 1.8 & 34.40 & 910 & 48 & 182 \\
GF3b $^{1}$ & 1.8 & 33.87 & 792 & 42 & 158 \\
GF4 & 2.5 & 26.00 & 734 & 39 & 147 \\
\hline
\end{tabular}

${ }^{1}$ GF3a specimen is renamed as GF3b at the end of 1,200,000 load cycles.

The strains are measured during the test under the steel bottom flange (SS.01, SS.02, SS.09 and SS.10) and under the top flange (SS.03 and SS.14) (see Figure 9). The data obtained from these measurements are presented in Table 4. The stress range formed on the fatigue critical points (FCR) at the tips of the welds where the stiffeners are connected to the bottom flange is obtained using these data. In the FCR regions of the specimens, a strain range of $0.57 \varepsilon_{\mathrm{y}}-0.32 \varepsilon_{\mathrm{y}}$, and a stress range of $218-121 \mathrm{MPa}$ occurred during cyclic loading. The strain and stress ranges in the FCR regions are considered as the average of the data collected from the four points on the right and left of the stiffeners.

Table 4. Strain and stress range in FCR regions.

\begin{tabular}{|c|c|c|c|c|c|c|c|c|c|}
\hline \multirow{2}{*}{ Specimen } & \multicolumn{6}{|c|}{ Strain Range $(\mu \varepsilon)$} & \multirow{2}{*}{$\begin{array}{c}\begin{array}{c}\text { Average } \\
\text { Strain Range } \\
(\mu \varepsilon)\end{array} \\
\text { FCR }\end{array}$} & \multirow{2}{*}{$\begin{array}{c}\text { Average Strain } \\
\text { Range/Yield } \\
\text { Strain (\%) }\end{array}$} & \multirow{2}{*}{$\begin{array}{c}\begin{array}{c}\text { Average } \\
\text { Stress Range } \\
(\mathrm{MPa})\end{array} \\
\text { FCR }\end{array}$} \\
\hline & SS.01 & SS.02 & SS.03 & SS.09 & SS.10 & SS.14 & & & \\
\hline GF1 & 1206 & 1182 & 571 & 1138 & 1153 & 581 & 1090 & 57 & 218 \\
\hline GF2 & 998 & 1006 & 479 & 964 & 943 & 460 & 912 & 48 & 182 \\
\hline $\mathrm{GF}^{3} \mathrm{a}^{1}$ & 860 & 863 & 460 & 869 & 833 & 456 & 796 & 42 & 159 \\
\hline GF3b ${ }^{1}$ & 767 & 769 & 212 & 754 & 713 & 181 & 708 & 37 & 142 \\
\hline GF4 & 635 & 680 & 375 & 630 & 658 & 321 & 605 & 32 & 121 \\
\hline
\end{tabular}

${ }^{1}$ GF3a specimen is renamed as GF3b at the end of 1,200,000 load cycles. 
Fatigue failure occurs with three stages as the onset of fatigue, crack formation and fatigue fracture. Strain data are collected during cyclic loading at the points where the fatigue is expected to occur (SS.01, SS.02, SS.09 and SS.10). In the specimens with fatigue fracture, as cyclic loading continues, the strain range at any of these points begins to increase, unlike the others. The related point is assumed as the onset of fatigue. After the onset of fatigue, at this point or on the other side of the same stiffener, the strain values increase rapidly, and the fatigue crack occurs over time. The fatigue fracture occurs by the propagation of this crack through the bottom flange and the height of the web. If the strains at the points where fatigue is expected change similarly during cyclic loading, fatigue crack and fatigue fracture do not occur.

Fatigue test results of the specimens are summarized in Table 5. The onset of fatigue on GF1 and GF2 specimens that are subjected to cyclic loads with stress range of 218 and $182 \mathrm{MPa}$, are observed at the reach of 275,000 and 400,000 cycles, respectively. Fatigue crack occurred when approximately $45 \%$ more of this cycle number is reached. Fatigue fracture occurred shortly after the formation of the fatigue crack. Although the cycles of GF3a, GF3b and GF4 are reached to 4,438,000, 1,200,000 and $4,000,000$ respectively, no onset of fatigue was observed.

Table 5. Fatigue test results of the specimens.

\begin{tabular}{cccccccc}
\hline Specimen & $\begin{array}{c}\text { Average Strain } \\
\text { Range/Yield } \\
\text { Strain (FCR) (\%) }\end{array}$ & $\begin{array}{c}\text { Average Stress } \\
\text { Range (FCR) } \\
\text { (MPa) }\end{array}$ & $\begin{array}{c}\text { Number } \\
\text { of } \\
\text { Cycles }\end{array}$ & $\begin{array}{c}\text { Fatigue } \\
\text { Crack }\end{array}$ & $\begin{array}{c}\text { Fatigue } \\
\text { Beginning }\end{array}$ & $\begin{array}{c}\text { Crack } \\
\text { Beginning }\end{array}$ & $\begin{array}{c}\text { Fatigue } \\
\text { Fracture }\end{array}$ \\
\hline GF1 & 57 & 218 & 407,000 & Yes & 275,000 & 403,000 & 407,000 \\
GF2 & 48 & 182 & 584,800 & Yes & 400,000 & 572,400 & 584,800 \\
GF3a ${ }^{1}$ & 42 & 159 & $1,200,000$ & No & - & - & - \\
GF3b $^{1}$ & 37 & 142 & $4,000,000$ & No & - & - & - \\
GF4 & 32 & 121 & $4,438,000$ & No & - & - & - \\
\hline \multicolumn{7}{c}{}
\end{tabular}

In Figure 24a,b, the stress range-number of cycles (S-N) data of the fatigue tests performed in this study and data of some relevant studies conducted on this subject are compared. As mentioned in the previous sections, the type of detail that the stiffeners are welded to the web and flanges of the steel beam is included in category $\mathrm{C}^{\prime}$ according to AASHTO LRFD [8]. According to AASHTO, the fatigue threshold of category $\mathrm{C}^{\prime}$ is $82.7 \mathrm{MPa}$, and the cycle number is $2,545,927$. When $\mathrm{S}-\mathrm{N}$ data of the specimens are compared, it is seen that the fatigue strength of specimens is above the one specified for category $C^{\prime}$. It can be said that the code's safety margin is conservative and the code remains on the safe side.

Although the data of GF1 and GF2 specimens with cyclic loads applied at the stress ranges of 218 and $182 \mathrm{MPa}$ in the fatigue critical regions are above the category $\mathrm{C}^{\prime}$, these results are compatible with the ones obtained by Fisher et al. [9] and Albrecht and Friedland [63]. No onset of fatigue and fatigue fracture is observed in the GF4 and GF3b specimens' tests, where 4,438,000 and 4,000,000 cycles are reached in the stress range of 121 and $142 \mathrm{MPa}$. Although these specimens are loaded at a higher stress range and 1.6 times higher cycles than the fatigue threshold specified for category $\mathrm{C}^{\prime}$, the test is terminated because no signs for the onset of fatigue are detected.

In the existing buildings, the vibration-based structural health monitoring techniques are generally used. In these techniques, the relation between the changes in the stiffness of the structure and the damages is aimed to be established. In the present study, it is observed that the change in the stiffness of the structure is not a determinant parameter for the prediction of fatigue damages. Thus, it is believed that it is not possible to determine the fatigue damages with the vibration-based monitoring techniques. Recently, strain-based monitoring systems have been used in some significant buildings. The results of the present study reveal that strain-based monitoring techniques should be used for the determination of fatigue damages. The critical point here is which detail should be monitored. In steel bridges with critical fatigue details specified in AASHTO LRFD [8], the fatigue details with the 
maximum stress range should be determined by calculations and these points should be monitored using strain-based methods. The shape of the crack that may occur in the fatigue critical details is shown in AASHTO LRFD [8]. The changes in strain should be monitored by installing strain gauges perpendicular to this crack.

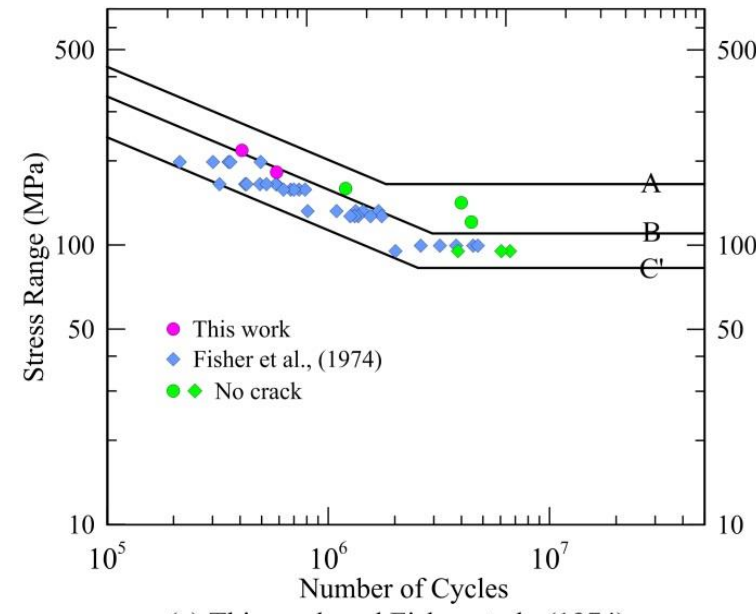

(a) This work and Fisher et al., (1974)

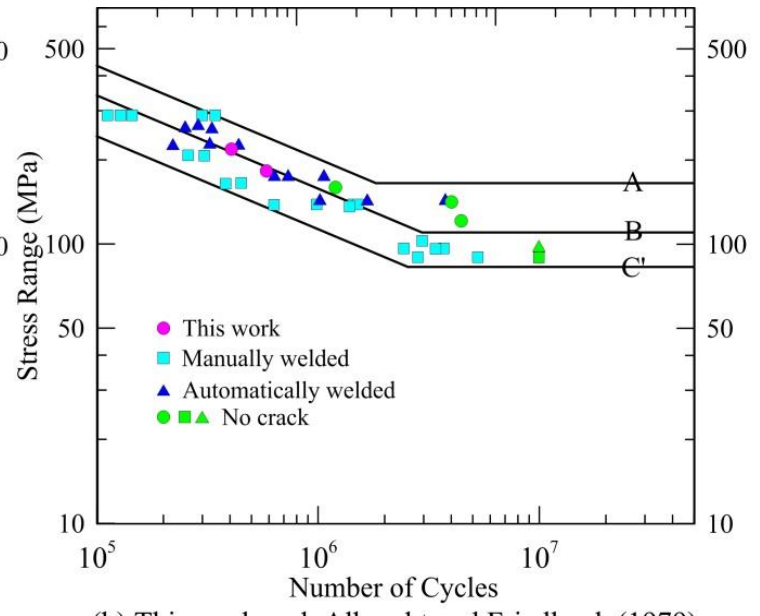

(b) This work and, Albrecht and Friedland, (1979)

Figure 24. S-N data of the specimens and comparisons.

The main factor that determines the fatigue behavior is the stress/strain range in the fatigue critical detail of the steel beam. The reduction of the yield strength, modulus of elasticity of concrete and compressive strength of concrete are not directly related to fatigue behavior. However, the effect of these factors on the stress range formed in the fatigue critical details has a significance. Although different failure modes caused by the connection details between concrete deck and steel beam are not directly related to fatigue behavior, they may be effective on fatigue behavior by changing the stress range in the fatigue critical details.

The effect of scale is not examined in this study. In Figure 24a,b, some important studies in the literature are shown which are also used in the determination of fatigue category $C^{\prime}$ in AASHTO LRFD [8]. The cross-sections used in the specimens of these studies have nearly real-scaled cross-sections used in bridges. In the present study, smaller scaled specimens are used. However, as can be seen in these figures, the results of the present study are consistent with the results of AASHTO LRFD [8] and other important studies. There are also other studies in the literature in which fatigue tests are performed on similar small-scaled specimens.

The specimens without cracks and fatigue fractures after cyclic loading are monotonically loaded to determine the residual strength, and the results are compared with the reference specimen's (GS) which was not subjected to cyclic loads. Load-deflection curves of these specimens are presented in Figure 25. The points that represent the yielding of the steel beam and the crushing of concrete in the concrete deck are marked on these curves. The specimen GF4 is loaded with 4,438,000 cycles, and the specimen GF3 (GF3a and GF3b) is loaded with 5,200,000 cycles. The test of monotonic loading is started with $\delta=32.28 \mathrm{~mm}$ permanent deflection caused by the accidental overloading of the specimen GF3 during cyclic loading. All specimens are collapsed due to the buckling of rebars after crushing of concrete in the deck. As a result of the monotonic loading at the end of cyclic loading, no significant decrease is observed in the stiffness, yield strength and ultimate capacity of the specimens. These results are consistent with the ones presented in the study of Yen et al. [33]. Cyclic loading did not cause a significant decrease in the ultimate strength. 


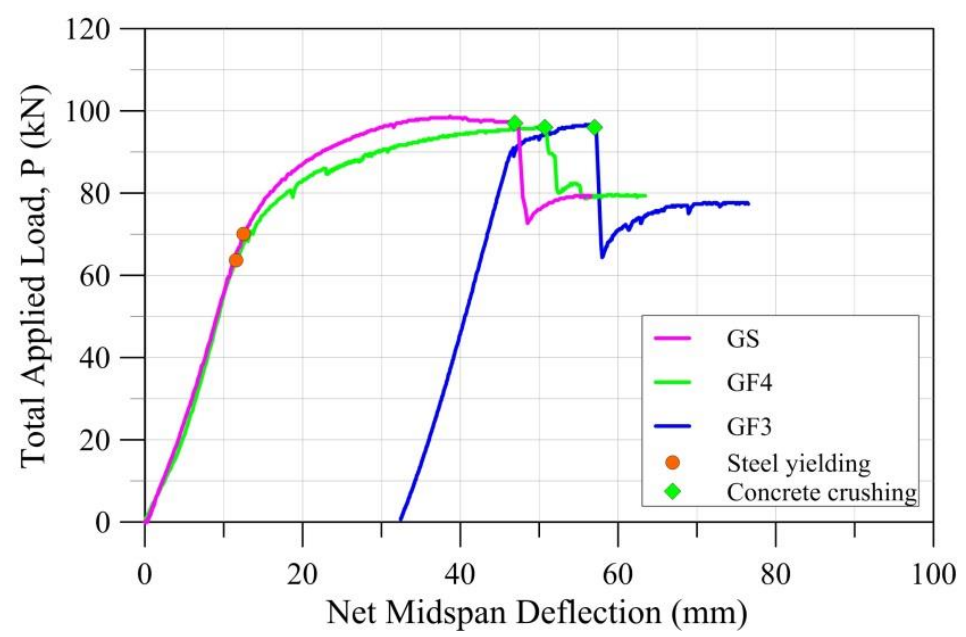

Figure 25. Load-deflection curves of the specimens.

\section{Conclusions}

In this study, the data types that should be monitored during the service life of a bridge are investigated in order to predict the fatigue damages in steel-concrete composite bridges with welded full depth transverse stiffeners (fatigue-sensitive detail). In this context, the relationship between the fatigue damages and the variables such as deflection, stiffness and deformations (strains) during cyclic loading has been revealed by an experimental study.

- The critical fatigue details of steel-concrete composite girder bridges that have reached or are at the end of their design life should be closely scrutinized. The structural safety and state of these bridges in terms of fatigue should be determined by strain-based measurements. The strains in the fatigue critical details should be monitored at regular intervals to check whether the onset of fatigue exists or not. Any increase in the strain range of one of these details different than the others indicates the onset of fatigue.

- The changes in deflection and stiffness are not sufficient parameters for the determination of fatigue life. The change in stiffness will be less effective if the systems with a higher degree of indeterminacy are considered. There is no significant reduction in stiffness and strength of beams which do not exhibit fatigue behavior after cyclic loading.

- S-N data obtained from the specimens are above the limits defined for category $\mathrm{C}^{\prime}$ in AASHTO LRFD [8]. This is an expected situation. The most unfavorable cases of the fatigue tests of the details are considered in defining the fatigue categories according to AASHTO LRFD [8]. In this respect, the code considers a conservative safety margin and remains on the safe side. The S-N data of the specimens are consistent with those of other studies in the literature.

- The vibration-based monitoring techniques, which are frequently used to determine the damage state of existing structures, are not sufficient to detect fatigue damages. In this study, it is found that the change in strain in fatigue critical details is determinant of fatigue behavior rather than the change in the stiffness. Thus, the fatigue details with the maximum stress range should be determined by calculations, and these points should be monitored using strain-based methods in steel bridges with critical fatigue details specified in AASHTO LRFD [8].

The future work offered by the authors about the scope of this paper consists of; performing full-scale tests to determine the effect of scale in future studies, and examining different proportions of weld thickness to the thickness of welded sheets in these tests; investigation of the effect of different damage types and strengthening methods on fatigue behavior; modelling of specimens by finite element method using various parameters, and examining the relationship between these parameters and test results. 
Author Contributions: Conceptualization, B.G. and A.I.; investigation, B.G.; methodology, B.G. and A.I.; supervision A.I. and N.K.O.; writing—original draft, B.G. and A.I.; writing-review \& editing, B.G. All authors have read and agreed to the published version of the manuscript.

Funding: This work was supported by the Istanbul University, BAP 2138 project and TUBITAK BIDEB Domestic PhD Scholarship Program.

Acknowledgments: We would like to thank ITU Structural and Earthquake Engineering Laboratory staff for their precious contribution and support to this study. For the financial support provided within the scope of research project number 2138 and TUBITAK BIDEB Domestic PhD Scholarship Program, we would like to thank the Scientific Research Projects Unit of Istanbul University and TUBITAK. In addition, we appreciate the materials, equipment and technical support provided by the following firms; BS Engineering, AMDS Rozak, Cagla Engineering and Architecture, AS Civata, BMS Hazir Demir, Mega Consulting, BASF and BETONSA.

Conflicts of Interest: The authors declare no conflict of interest.

\section{References}

1. Wöhler, A. August Wöhler. 1850. Available online: http://en.wikipedia.org/wiki/August_W\%C3\%B6hler (accessed on 13 December 2019).

2. Stephens, R.I.; Fatemi, A.; Stephens, R.R.; Fuchs, H.O. Metal Fatigue in Engineering, 2nd ed.; John Wiley \& Sons: New York, NY, USA, 2001.

3. Fisher, J.W. Fatigue and Fracture in Steel Bridges: Case Studies; Wiley Interscience: London, UK, 1984.

4. Fisher, J.W.; Kulak, G.L.; Smith, I.F.C. A Fatigue Primer for Structural Engineers; National Steel Bridge Alliance: Chicago, IL, USA, 1998.

5. Kazuhiro, N.; Jun, M.; Takayuki, M. Study on the fatigue of steel highway bridges in Japan. Constr. Build. Mater. 1998, 12, 133-141.

6. Al-Emrani, M.; Nilsson, M.; Lukic, M. Bridge Fatigue Guidance-A European Research Project; European Commission, Research Fund for Coal and Steel: Luxembourg, 2011.

7. Josi, G. Reliability-Based Management of Fatigue Failures. Ph.D. Thesis, University of Alberta, Edmonton, AB, Canada, 2010.

8. AASHTO LRFD. AASHTO LRFD Bridge Design Specifications, 8th ed.; American Association of State Highway and Transportation Officials: Washington, DC, USA, 2017.

9. Fisher, J.W.; Albrecht, P.A.; Yen, B.T.; Klingerman, D.J.; McNamee, B.M. Fatigue Strength of Steel Beams with Welded Stiffeners and Attachments; Transportation Research Board; National Research Council: Washington, DC, USA, 1974.

10. Pass, J.D.; Frank, K.H.; Yura, J.A. Fatigue Behavior of Longitudinal Transverse Stiffener Intersection; U.S. Department of Transportation Federal Highway Administration: Washington, DC, USA, 1983.

11. Klippstein, K.H.; Schilling, C.G. Pilot study on the constant and variable amplitude behavior of transverse stiffener welds. J. Constr. Steel Res. 1989, 12, 229-252. [CrossRef]

12. Fisher, J.W.; Nussbaumer, A.; Keating, P.B.; Yen, B.T. Resistance of Welded Details under Variable Amplitude Long-Life Fatigue Loading; Transportation Research Board; National Research Council: Washington, DC, USA, 1993.

13. Wright, W.J. Long-life fatigue behavior of welded steel-bridge girder details. In Proceedings of the ASCE Structures Congress, Irvine, CA, USA, 19-21 April 1993.

14. Sakano, M.; Wahab, M.A. Fatigue strength of welded transverse stiffener joints under variable amplitude loading. Int. J. Press. Vessel. Pip. 1998, 75, 1037-1045. [CrossRef]

15. Woo, S.I.; Jung, K.S.; Albrech, P. Fatigue behavior of transverse stiffener subjected to variable amplitude loading. KSCE J. Civ. Eng. 2002, 6, 151-160. [CrossRef]

16. Jang, B.S.; Ito, H.; Kim, K.S.; Suh, Y.S.; Jeon, H.T.; Ha, Y.S. A study of fatigue crack propagation at a web stiffener on a longitudinal stiffener. J. Mar. Sci. Technol. 2010, 15, 176-189. [CrossRef]

17. Triamlumlerd, W.; Lenwari, A. Analysis of fatigue crack propagation in steel I-beams with welded transverse stiffeners subjected to in-plane loadings. Eng. J. 2017, 21, 307-324. [CrossRef]

18. Endeshaw, H.B.; Osire, S.E.; Alemayehu, F.M. Evaluation of Fatigue Crack Propagation of Gears Considering Uncertainties in Loading and Material Properties. Sustainability 2017, 9, 2200. [CrossRef]

19. Fisher, J.W.; Frank, K.H.; Hirt, M.A.; McName, B.M. Effect of Weldments on the Fatigue Strength of Steel Beams; Transportation Research Board; National Research Council: Washington, DC, USA, 1970. 
20. Schilling, C.G.; Klippstein, K.H.; Barsom, J.M.; Blake, G.T. Fatigue of Welded Steel Bridge Members under Variable Amplitude Loadings; Transportation Research Board, National Research Council: Washington, DC, USA, 1978.

21. Slutter, R.G.; Fisher, J.W. Fatigue Strength of Shear Connectors. 1967. Available online: http://digital.lib. lehigh.edu/fritz/pdf/316_2.pdf (accessed on 13 December 2019).

22. Taplin, G.; Grundy, P. Steel-concrete composite beams under repeated load. In Proceedings of the Composite Construction in Steel and Concrete IV, Banff, AB, Canada, 28 May-2 June 2000; pp. 37-50. [CrossRef]

23. Hanswille, G.; Porsch, M.; Ustundag, C. Resistance of headed studs subjected to fatigue loading: Part I: Experimental study. J. Constr. Steel Res. 2007, 63, 475-484. [CrossRef]

24. Wang, Y.H.; Nie, J.G.; Li, J.J. Study on fatigue property of steel-concrete composite beams and studs. J. Constr. Steel Res. 2014, 94, 1-10. [CrossRef]

25. Ovuoba, B.; Prinz, G.S. Fatigue capacity of headed shear studs in composite bridge girders. J. Bridge Eng. 2016, 21, 04016094. [CrossRef]

26. Sjaarda, M.; Porter, T.; West, J.S.; Walbridge, S. Fatigue behavior of welded shear studs in precast composite beams. J. Bridge Eng. 2017, 22, 04017089. [CrossRef]

27. Wang, B.; Huang, Q.; Liu, X.; Li, W. Experimental investigation of steel-concrete composite beams with different degrees of shear connection under monotonic and fatigue loads. Adv. Struct. Eng. 2017, 21, 227-240. [CrossRef]

28. El-Zohairy, A.; Salim, S.; Saucier, A. Fatigue tests on steel-concrete composite beams subjected to sagging moments. J. Struct. Eng. 2019, 145, 04019029. [CrossRef]

29. Albrecht, P.; Lenwari, A. Fatigue strength of repaired prestressed composite beams. J. Bridge Eng. 2008, 13, 409-417. [CrossRef]

30. El-Zohairy, A.; Salim, H.; Saucier, A. Steel-Concrete Composite Beams Strengthened with Externally Post-Tensioned Tendons under Fatigue. J. Bridge Eng. 2019, 24, 04019027. [CrossRef]

31. Dawood, M.; Rizkalla, S.; Sumner, E. Fatigue and overloading behavior of steel-concrete composite flexural members strengthened with high modulus CFRP materials. J. Compos. Constr. 2007, 11, 659-666. [CrossRef]

32. Lin, W.; Yoda, T.; Taniguchi, N. Fatigue tests on straight steel-concrete composite beams subjected to hogging moment. J. Constr. Steel Res. 2013, 80, 42-56. [CrossRef]

33. Yen, J.Y.R.; Lin, Y.; Lai, M.T. Composite beams subjected to static and fatigue Loads. J. Struct. Eng. 1997, 123, 765-771. [CrossRef]

34. Pnevmatikos, N.G.; Blachowski, B.; Hatzigeorgiou, G.D.; Swiercz, A. Wavelet analysis based damage localization in steel frames with bolted connections. Smart Struct. Syst. 2016, 18, 1189-1202. [CrossRef]

35. Pnevmatikos, N.G.; Hatzigeorgiou, G.D. Damage detection of framed structures subjected to earthquake excitation using discrete wavelet analysis. Bull. Earthq. Eng. 2016, 15. [CrossRef]

36. Pnevmatikos, N.G.; Papagiannopoulos, G.A.; Hatzigeorgiou, G. Fatigue assessment of a steel frame subjected to a number of earthquake excitations. Procedia Struct. Integr. 2018, 10, 195-202. [CrossRef]

37. Modares, M.; Waksmanski, N. Overview of structural health monitoring for steel bridges. Pract. Period. Struct. Des. Constr. 2013, 18, 187-191. [CrossRef]

38. Hao, S. I-35W bridge collapse. J. Bridge Eng. 2010, 15, 608-614. [CrossRef]

39. Abdel-Ghaff, A.M.; Scanlan, R.H. Ambient vibration studies of golden gate bridge: I suspended structure. J. Eng. Mech. 1985, 111, 463-482. [CrossRef]

40. Brownjohn, J.M.W.; Magalhaes, F.; Caetano, E.; Cunha, A.; Au, I.; Lam, P. Dynamic testing of the Humber Suspension Bridge. In Proceedings of the International Conference of Experimental Vibration Analysis for Civil Engineering Structures, Wroclaw, Poland, 14-16 October 2009.

41. Conte, J.P.; He, X.; Moaveni, B.; Masri, S.F.; Caffrey, J.P.; Wahbeh, M.; Tasbihgoo, F.; Whang, D.H.; Elgamal, A. Dynamic testing of Alfred Zampa Memorial Bridge. J. Struct. Eng. 2008, 134, 1006-1015. [CrossRef]

42. Ko, J.M.; Sun, Z.G.; Ni, Y.Q. Multi-stage identificationcheme for detecting damage in cable-stayed Kap Shui Mun Bridge. Eng. Struct. 2002, 24, 857-868. [CrossRef]

43. Pakzad, S.N.; Fenves, G.L. Statistical analysis of vibration modes of a suspension bridge using spatially densewireless sensor network. J. Struct. Eng. 2009, 135, 863-872. [CrossRef]

44. Peeters, B.; Roeck, G.D. One-year monitoring of the Z24-Bridge: Environmental effects versus damage events. Earthq. Eng. Struct. Dyn. 2001,30,149-171. [CrossRef]

45. Siringoringo, D.M.; Fujino, Y. System identification of suspension bridge from ambient vibration response. Eng. Struct. 2008, 30, 462-477. [CrossRef] 
46. Zhang, J.; Prader, J.; Moon, F.; Grimmelsman, K.A.; Aktan, E.; Sayama, A. Experimental vibration analysis for structural identification of a long span suspension bridge. ASCE J. Eng. Mech. 2013, 139, 748-759. [CrossRef]

47. Zhang, J.; Hong, W.; Tang, Y.; Yang, C.; Wu, G.; Wu, Z. Structural health monitoring of a steel stringer bridge with area sensing. Struct. Infrastruct. Eng. 2014, 10, 1049-1058. [CrossRef]

48. Mao, J.; Wang, H.; Li, J. Strain monitoring case study: Sutong Cable-stayed Bridge. J. Bridge Eng. 2019, 24, 1-14. [CrossRef]

49. Spencer, B.F.; Ruiz-Sandoval, M.E.; Kurata, N. Smart sensing technology: Opportunities and challenges. Struct. Control Health Monit. 2004, 11, 349-368. [CrossRef]

50. Ko, J.M.; Ni, Y.Q. Technology developments in structural health monitoring of large-scale bridges. Eng. Struct. 2005, 27, 1715-1725. [CrossRef]

51. Wang, H.; Li, A.; Niu, J.; Zong, Z.; Li, J. Long-termmonitoring of wind characteristics at Sutong Bridge site. J. Wind Eng. Ind. Aerodyn. 2013, 115, 39-47. [CrossRef]

52. Nagarajaiah, S.; Erazo, K. Structural monitoring and identification of civil infrastructure in the United States. Struct. Monit. Maint. 2016, 3, 51-59. [CrossRef]

53. Wang, H.; Mao, X.; Huang, J.H.; Li, A.Q. Modal identification of Sutong cable-stayed bridge under typhoon Haikui using wavelet transform method. J. Perform. Constr. Facil. 2016, 30, 04016001. [CrossRef]

54. Mao, J.X.; Wang, H.; Xun, Z.X.; Zou, Z.Q. Variability analysis on modal parameters of Runyang Bridge during typhoon Masta. Smart Struct. Syst. 2017, 19, 653-663.

55. Ni, Y.Q.; Ye, X.W.; Ko, J.M. Monitoring-based fatigue reliability assessment of steel bridges: Analytical model and application. J. Struct. Eng. 2010, 136, 1563-1573. [CrossRef]

56. Connor, R.J.; Mahmoud, H.N.; Bowman, C.A. Results of the Fatigue Evaluation and Field Monitoring of the I-39 Northbound Bridge over the Wisconsin River; ATLSS Rep. 05-04; Lehigh University: Bethlehem, PA, USA, 2005.

57. Deng, Y.; Liu, Y.; Feng, D.M.; Li, A.Q. Investigation of fatigue performance of welded details in long-span steel bridges using long term monitoring strain data. Struct. Control Health Monit. 2015, 22, 1343-1358. [CrossRef]

58. Frangopol, D.M.; Strauss, A.; Kim, S. Bridge reliability assessment based on monitoring. J. Bridge Eng. 2008, 13, 258-270. [CrossRef]

59. Gunes, B. Fatigue Behaviour of Steel-Concrete Composite Beams Strengthened with Carbon Fiber Reinforced Polymers (CFRP). Ph.D. Thesis, İstanbul University, Engineering Faculty, Civil Engineering Department, İstanbul, Turkey, 2013.

60. TS EN 12390-3. Testing Hardened Concrete_Part 3: Compressive Strength of Test Specimens; TSE: Ankara, Turkey, 2003.

61. TS EN ISO 6892-1. Metallic Materials—Tensile Testing_Part 1: Method of Test at Room Temperature; TSE: Ankara, Turkey, 2010.

62. Gunes, B.; Ilki, A.; Oztorun, N.K. The effects of pitting corrosion and CFRP repair on the behaviour of steel-concrete composite beams. J. Compos. Constr. 2019. under review.

63. Albrecht, P.; Friedland, I.M. Fatigue-limit effect on variable amplitude fatigue of stiffeners. J. Struct. Div. $1979,105,2657-2675$.

(C) 2019 by the authors. Licensee MDPI, Basel, Switzerland. This article is an open access article distributed under the terms and conditions of the Creative Commons Attribution (CC BY) license (http://creativecommons.org/licenses/by/4.0/). 